\title{
Hydrological, chemical, and isotopic budgets of Lake Chad: a quantitative assessment of evaporation, transpiration and infiltration fluxes
}

\author{
Camille Bouchez $^{1}$, Julio Goncalves ${ }^{1}$, Pierre Deschamps ${ }^{1}$, Christine Vallet-Coulomb ${ }^{1}$, Bruno Hamelin ${ }^{1}$, \\ Jean-Claude Doumnang ${ }^{2}$, and Florence Sylvestre ${ }^{1}$ \\ ${ }^{1}$ CEREGE UM34, Aix-Marseille Université, CNRS, IRD, Collège de France, 13545 Aix en Provence, France \\ ${ }^{2}$ Laboratoire de Géologie, Géomorphologie et Télédétection, Faculté des Sciences Exactes et Appliquées, \\ Université de NDjaména, NDjaména, Republic of Chad
}

Correspondence to: Camille Bouchez (bouchezcamille@gmail.com)

Received: 1 October 2015 - Published in Hydrol. Earth Syst. Sci. Discuss.: 30 October 2015

Revised: 22 March 2016 - Accepted: 5 April 2016 - Published: 26 April 2016

\begin{abstract}
In the Sahelian belt, Lake Chad is a key water body for 13 million people, who live on its resources. It experiences, however, substantial and frequent surface changes. Located at the centre of one of the largest endorheic basins in the world, its waters remain surprisingly fresh. Its low salinity has been attributed to a low infiltration flow whose value remains poorly constrained. Understanding the lake's hydrological behaviour in response to climate variability requires a better constraint of the factors that control its water and chemical balance. Based on the three-pool conceptualization of Lake Chad proposed by Bader et al. (2011), this study aims to quantify the total water outflow from the lake, the respective proportions of evaporation $(E)$, transpiration $(T)$, and infiltration $(I)$, and the associated uncertainties. A Bayesian inversion method based on lake-level data was used, leading to total water loss estimates in each pool $(E+T+I=\mathrm{ETI})$. Sodium and stable isotope mass balances were then used to separate total water losses into $E, T$, and $I$ components. Despite the scarcity of representative data available on the lake, the combination of these two geochemical tracers is relevant to assess the relative contribution of these three outflows involved in the control of the hydrological budget. Mean evapotranspiration rates were estimated at $2070 \pm 100$ and $2270 \pm 100 \mathrm{~mm} \mathrm{yr}^{-1}$ for the southern and northern pools, respectively. Infiltration represents between 100 and $300 \mathrm{~mm} \mathrm{yr}^{-1}$ but most of the water is evapotranspirated in the first few kilometres from the shorelines and does not efficiently recharge the Quaternary aquifer. Transpiration is shown to be significant, around $300 \mathrm{~mm} \mathrm{yr}^{-1}$ and reaches
\end{abstract}

$500 \mathrm{~mm} \mathrm{yr}^{-1}$ in the vegetated zone of the archipelagos. Hydrological and chemical simulations reproduce the marked hydrological change between the normal lake state that occurred before 1972 and the small lake state after 1972 when the lake surface shrunk to a one-tenth of its size. According to our model, shrinking phases are efficient periods for salt evacuation from the lake towards the phreatic aquifer.

\section{Introduction}

The severe drought that affected the Sahel in the 1970s1980 s is one of the major signs of climate variability recorded on a global scale during the 20th century (Giorgi, 2002). The surface of Lake Chad decreased from $21000 \mathrm{~km}^{2}$ in 1960 to $2500 \mathrm{~km}^{2}$ in 1987 (Lemoalle et al., 2014), illustrating the consequences of climatic changes in the Sahelian belt (Ballatore and Muhandiki, 2002; NASA Earth Observatory, 2001). Lake surface area oscillations have major socio-economic impacts on populations established along the lakeshores who depend on its fresh water and halieutic resources for their livelihood (Hutchinson et al., 1992; Sarch and Birkett, 2000; Sarch, 2001). It was initially thought that withdrawals of water, mainly for irrigation, contributed to the lake decline observed during the 80s and 90s (Coe and Foley, 2001), but more recent studies have shown that withdrawals were very likely overestimated and argue that extraction for irrigation is negligible in the hydrological budget of 
the lake (Lemoalle et al., 2014). Since 2000, the lake surface area has increased, reaching $14000 \mathrm{~km}^{2}$ in April 2013 due to more favourable rainfall in the western Sahel (Lebel and Ali, 2009). This recent evolution of Lake Chad clearly indicates that its variability is essentially driven by variations in the monsoon regime over its southern drainage basin, combined with a very short residence time of the water in this system.

Although it is the terminal lake of an endorheic basin dominated by evaporation $\left(\sim 2000 \mathrm{~mm} \mathrm{yr}^{-1}\right)$, Lake Chad waters remain surprisingly fresh (Carmouze, 1979; Roche, 1975). It has been suggested that the chemical regulation of Lake Chad is controlled both by geochemical precipitation and clay neoformation in the lake (Carmouze, 1983; Gac et al., 1977) and more significantly by infiltration of the lake water into the underlying Quaternary aquifer (Roche, 1975). The aquifer connected with the lake is the major source of water for domestic use but its waters in some areas show total dissolved salt concentrations above the recommended values (Abderamane et al., 2013).

A thorough estimate of the hydrological and chemical fluxes of Lake Chad is crucial to understand its variability and chemical regulation as well as to constrain the relationship between the lake and the Quaternary aquifer. Despite considerable efforts to evaluate evaporation and infiltration out of this lacustrine system, much remains to be done in order to better constrain the hydrological and salinity budget of Lake Chad, especially in its present state, characterized by seasonal or perennial pools. For instance, the impact of transpiration, which might be a significant process impacting the hydrological budget owing to dense vegetation on the lake (Jasechko et al., 2013), has so far never been taken into account. Different lake water balance models were previously implemented to simulate fluctuations in the level of Lake Chad (Olivry et al., 1996; Vuillaume, 1981). An integrated lake-catchment approach, coupling the distributed surface water balance calculated over the basin (Integrated Biosphere Model, IBIS) with runoff transported across the land surface (hydrological routing algorithm, HYDRA) described using a digital elevation model (DEM) approach yielded a good representation of the river discharge of the basin and the lakelevels in the eastern part (Coe and Foley, 2001). Nevertheless, this model was unable to distinguish the different states and pools of the lake and groundwater-surface water interactions were not accounted for.

Infiltration of lake waters into the Quaternary aquifer was evaluated by isotopic studies (Fontes et al., 1970b; Gaultier, 2004; Zairi, 2008) or by quantitative approaches based on simple water or salt budgets (Bader et al., 2011; Carmouze, 1972; Roche, 1980), direct estimates of seepage velocities (Isihoro and Matisoff, 1990) or hydrogeological models (Isihoro et al., 1996; Leblanc, 2002). However, they lead to a large range of infiltration estimates of between 2 and $32 \%$ of the total inputs of the lake. The accurate quantification of leakage from lake waters is a challenging issue especially in semi-arid to arid environments (Gee and Hillel, 1988), as the estimates are highly dependent on the methods selected (LaBaugh et al., 1997). This suggests that a combination of different approaches is necessary to accurately estimate all the fluxes of the lake water balance. Chemical modelling using conservative elements has proved to be relevant to quantify groundwater outflows (LaBaugh et al., 1997; Troin et al., 2010; Vallet-Coulomb et al., 2001). Isotopic budgets have also been widely used to constrain lake water balances (Gibson, 2002; Gibson et al., 2002; Gonfiantini, 1986; Krabbenhoft et al., 1990; Sacks et al., 2013; Vallet-Coulomb et al., 2006). However, the combination of the two approaches has seldom been undertaken.

The objective of the present study is to make the best use of all available information on Lake Chad to combine for the first time hydrological, chemical, and isotopic mass balance approaches over the 1955-2011 period. This aims to (i) refine the range of the global total water losses of the Lake Chad system; (ii) determine the respective contributions of evaporation, infiltration, and transpiration in the system not completely explored so far; and (iii) assess the influence of infiltration on both the chemical regulation of the lake and the recharge and chemistry of the underlying aquifer.

\section{General description of the study site}

\subsection{Lake catchment settings}

The Lake Chad basin (LCB) is a 2.5 billion $\mathrm{km}^{2}$ hydrologically closed drainage basin located in central Africa, between Chad, Cameroon, Nigeria, Niger, and the Central African Republic and extending from 7 to $24^{\circ} \mathrm{E}$ and from 5 to $25^{\circ} \mathrm{N}$. It is bordered by high mountains, the Tibesti and the Hoggar in the north, the Adamaoua in the south, the Air in the west and the Ennedi in the east. The drainage basin is characterized by a south-north climatic gradient. The northern part lies in the Saharan climatic zone, dominated by low rainfall and high evaporation rates. The southern Sudanese part is under a monsoon regime and is the only hydrologically active part of the basin (about $610000 \mathrm{~km}^{2}$ ). The internal part of the LCB is a flat sedimentary depression, with a mean topographic slope of $1.3 \%$ (Le Coz et al., 2009) and Lake Chad is located in a small depression in the central Sahelian part (Fig. 1).

\subsection{Lake morphology}

Lake Chad is subdivided into three areas, the southern and the northern pools, separated by an east-west vegetationcovered sand barrier named the Great Barrier, and an island area in the east named the archipelagos (Fig. 1). These zones are either connected or disconnected depending on the lake level. Different states and morphologies of the lake have been described as a function of lake levels (Olivry et al., 1996). During the period on which this study focuses, Lake Chad oscillated between its normal state, corresponding to a sur- 

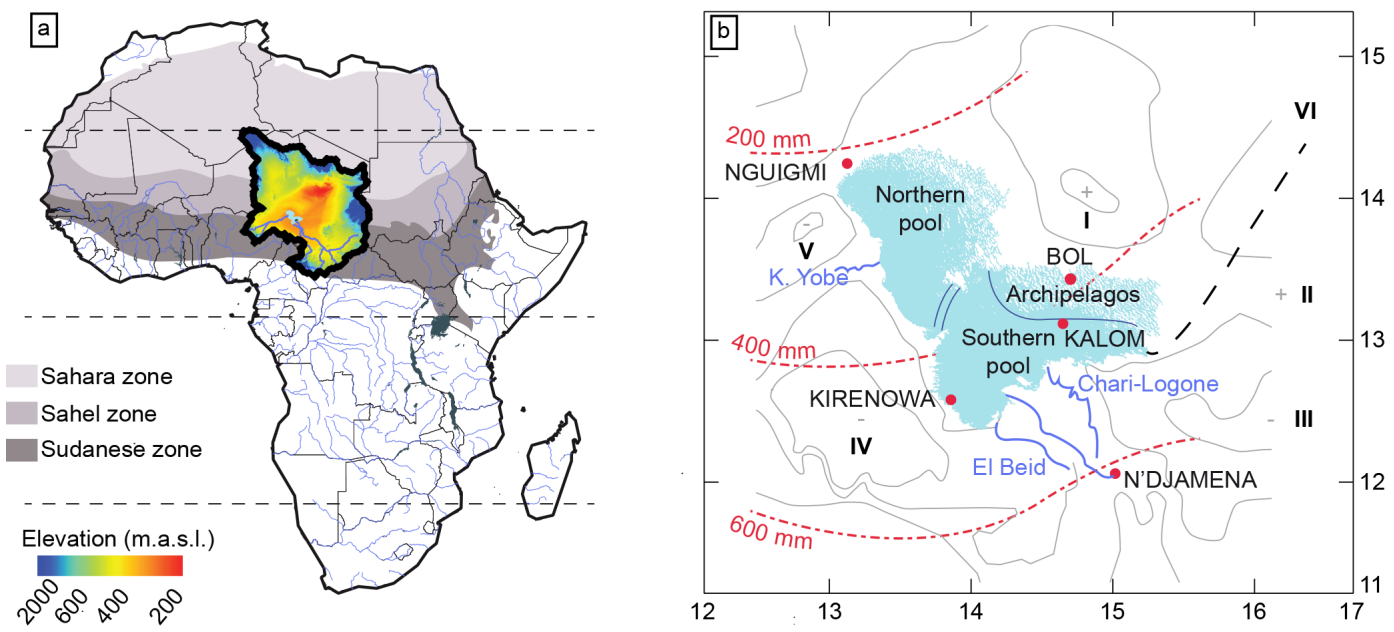

Figure 1. (a) Location of Lake Chad basin in Africa. Lake Chad (light blue) and its tributaries (blue) are figured in the African hydrological network (blue lines). The climatic zones in North Africa are presented. The elevation colour bar corresponds to the altitude and the black line is the boundary of Lake Chad basin. (b) Presentation of Lake Chad in its normal state. The three pools are depicted and the double line between the southern and the northern pools is the Great Barrier. The tributaries are shown in blue and mean rainfall rates in red. The piezometric map around the lake and its particular features are presented in grey lines, the piezometric domes: I - Kanem, II - Harr and depressions, III - Chari Baguirmi, IV - Bornu, V - Kadzell. The dotted black line represents the Bahr el Ghazal, a temporary outlet of the lake.

face area of about $20000 \mathrm{~km}^{2}$ occurring between 1950 and 1972 and its small state, below $15000 \mathrm{~km}^{2}$ (Olivry et al., 1996) since 1972. During its normal state, the mean water depth is about $3 \mathrm{~m}$ in the southern pool and $6 \mathrm{~m}$ in the northern pool. Lake levels occasionally exceed a threshold located in the eastern part of the southern pool, at $282.3 \mathrm{~m}$, leading to overflows in the Bahr-el-Ghazal channel, which drains water northward to the Bodele depression (Fig. 1). During the Holocene, the Bodele depression was filled and the lake Mega-Chad covered $350000 \mathrm{~km}^{2}$.

\subsection{Hydrological and chemical features of Lake Chad}

The Chari-Logone River flows from the Central African Republic along the Cameroon border into the southern shore of Lake Chad. It is the major tributary of the lake and accounts for almost $80-90 \%$ of the water inflow. Other inputs are the Komodougou Yobe River, which flows from Nigeria and Niger (5\%) into the northern pool and direct rainfall at the lake surface (5-10\%, Bader et al. (2011); Olivry et al. (1996). Lake Chad waters are subject to a high evaporation rate of about $2000 \mathrm{~mm} \mathrm{yr}^{-1}$, which is the major water loss of the lake, while infiltration remains small. In the normal state, river discharge is around $40 \mathrm{~km}^{3} \mathrm{yr}^{-1}$ and rainfall at the surface of the lake around $250 \mathrm{~mm} \mathrm{yr}^{-1}\left(4 \mathrm{~km}^{3} \mathrm{yr}^{-1}\right)$ for a lake volume of about $72 \mathrm{~km}^{3}$. Consequently, under the rough assumption of a steady state, the residence time of the waters in the lake is very short, about 1-2 years. With previous estimates of the annual infiltration into the Quaternary aquifer of nearly $5 \%$ of the lake volume, the residence time of a conservative element in the normal state is around $20-40$ years.
Lake Chad hydrological budget is thus controlled by the balance between rainfall in the southern part of the basin and evaporation over the lake surface. This balance directly governs not only on very short timescales the volume but also the lake surface because of the flat topography of the basin responsible for the lake shallowness.

\subsection{The regional Quaternary aquifer}

The lake is hydraulically connected to an unconfined aquifer of $500000 \mathrm{~km}^{2}$ (Schneider and Wolff, 1992). It is composed by an alternation of silts, sands and clays resulting from extended and restricted lacustrine phases during the Quaternary. The hydraulic gradient and thus groundwater flow around the lake is oriented from the lake towards the aquifer except at the north-eastern end of the lake (Fig. 1). The water table is characterized by three major piezometric depressions around the lake, Chari-Baguirmi, Kadzell, and Bornu and two piezometric domes, Harr and Kanem (Fig. 1). The origin of such features, also described in other phreatic aquifers in the Sahelian belt (Archambault, 1960; Aranyossy and Ndiaye, 1993), is still debated. The main assumption of a high and localized evapotranspiration rate associated with low hydraulic conductivities was confirmed in the LCB by a steadystate regional flow model of the Quaternary aquifer (Boronina and Ramillien, 2008). Isotopic studies suggest that the main recharge occurred during past humid periods (Leblanc, 2002; Leduc et al., 2000). Infiltration from both lake and rivers may also contribute locally to the recharge of this unconfined aquifer but its quantification remains an issue (Djoret, 2000; Zairi, 2008). 


\section{General approach: combination of water, chemical and isotopic mass balances}

In the case of a shallow closed lake where aquatic vegetation has a non-negligible role through transpiration fluxes, the hydrological, chemical, and stable isotopic mass balances are expressed as follows:

$$
\begin{aligned}
& \frac{\Delta V_{\mathrm{L}}}{\Delta t}=\left(S_{\mathrm{L}} \times[P-(E+T+I)]+Q_{\text {in }}\right)_{t-\Delta t} \\
& \frac{\Delta\left(V_{\mathrm{L}} \cdot C_{\mathrm{L}}\right)}{\Delta t}=\left(S_{\mathrm{L}} \times\left[P \cdot C_{\mathrm{P}}-I \cdot C_{\mathrm{L}}\right]+Q_{\text {in }} \cdot C_{\text {in }}\right)_{t-\Delta t} \\
& \frac{\Delta\left(V_{\mathrm{L}} \cdot \delta_{\mathrm{L}}\right)}{\Delta t}= \\
& \left(S_{\mathrm{L}} \times\left[P \cdot \delta_{\mathrm{P}}-(I+T) \cdot \delta_{\mathrm{L}}-E \cdot \delta_{\mathrm{E}}\right]+Q_{\text {in }} \cdot \delta_{\text {in }}\right)_{t-\Delta t}
\end{aligned}
$$

where $V_{\mathrm{L}}$ is the volume of the lake $\left(\mathrm{m}^{3}\right), S_{\mathrm{L}}$ the surface $\left(\mathrm{m}^{2}\right)$, $P$ the rainfall $\left(\mathrm{m} \mathrm{day}^{-1}\right), E$ the evaporation $\left(\mathrm{m} \mathrm{day}^{-1}\right), I$ the infiltration $\left(\mathrm{m} \mathrm{day}^{-1}\right), T$ the transpiration $\left(\mathrm{m} \mathrm{day}^{-1}\right), Q_{\text {in }}$ the river discharge $\left(\mathrm{m}^{3}\right.$ day $\left.^{-1}\right), C_{\mathrm{L}}, \delta_{\mathrm{L}}, C_{\mathrm{P}}, \delta_{\mathrm{P}}, C_{\mathrm{in}}$, and $\delta_{\text {in }}$ the concentrations ( $\mathrm{mg} \mathrm{L}^{-1}$ ) and isotopic compositions (\%o) of the lake, the rainfall and the rivers, and $\delta_{\mathrm{E}}$ the isotopic composition of the evaporated moisture. This set of balance equations assumes a perfect mixing at each time step. Considering a steady state of vegetation growth cycle in the lake, transpiration has no effect on salt balance but has the same role as infiltration for the isotopic mass balance since it does not induce any fractionation at stationary state (Welp et al., 2008). Therefore, in the chemical mass balance, infiltration is the only process exporting salts while in the stable isotope mass balance, evaporation is the only fractionating pathway.

According to Craig and Gordon (1965), the isotopic composition of the evaporated moisture above a lake can be calculated from the measured relative humidity $(h)$, the measured isotopic composition of the regional vapour $\left(\delta_{A}\right)$, the isotopic composition of the lake $\left(\delta_{\mathrm{L}}\right)$, the total fractionation coefficient $\left(\varepsilon^{*}\right)$, and the kinetic fractionation $\left(\varepsilon_{\mathrm{k}}\right)$ coefficient as follows:

$\delta_{\mathrm{E}}=\frac{\left(\delta_{\mathrm{L}}-\varepsilon^{*}\right) / \alpha-h \cdot \delta_{A}-\varepsilon_{\mathrm{k}}}{1-h+\varepsilon_{\mathrm{k}}}$,

$\varepsilon *=(\alpha-1)$

$\varepsilon_{\mathrm{k}}=(1-h) \cdot \theta \cdot n \cdot C_{D}$,

where $n, \theta$, and $C_{D}$ are turbulence parameters such that $n=1 / 2$ for an average turbulent flow (Gonfiantini, 1986), $C_{D}$ was determined experimentally as $C_{D}{ }^{18} \mathrm{O}=28.5 \%$, $C_{D}{ }^{2} \mathrm{H}=25.1 \%$ (Merlivat, 1978). Few studies have focused on the determination of the $\theta$ parameter. Its value is generally lower than 1 for a water body whose strong evaporation flux perturbs the atmospheric boundary layer (Horita et al., 2008), with a value of 0.88 estimated for the Great Lakes (Gat et al., 1994), and commonly used elsewhere. Nevertheless, a lower value $(\theta=0.5)$ has been estimated for the eastern Mediterranean (Gat, 1996), attributed to the high contrast between the air column above the sea surface and the advected air masses. Thus, since low values may be expected when humidity is not measured near the lake surface (Gat, 1996), and because the Lake Chad evaporative conditions are closer to the conditions of the eastern Mediterranean Sea than to those of the Great Lakes, we chose a value of 0.5 . The choice of this value is further discussed based on the slope of the evaporation line.

Recycling of evaporated moisture is able to influence the local atmosphere above the lake (Vallet-Coulomb et al., 2008; Jasechko et al., 2014). The impact of Lake Chad (normal size) and of its desiccation on regional climate has been investigated, using a mesoscale regional atmospheric model coupled to a soil-vegetation-atmosphere transfer model (Lauwaet et al., 2012), showing that whatever the size of the lake, lake evaporation does not affect significantly the atmospheric hydrological cycle and the total precipitation amounts. The authors calculate a moisture recycling ratio of less than $7 \%$ in the total studied area, that remains unchanged regarding the size of the lake. Even during episodes of lake Mega-Chad, covering $340000 \mathrm{~km}^{2}$, which is over a hundred times its current surface area, the contribution of Lake Chad to regional moisture remains low (Contoux et al., 2013). In addition, the humidity around Lake Chad, documented both from global data and local studies is low (around 0.4 in average), arguing for a small influence of local vapour recycling on the simulation of lake water isotopic composition. Therefore, although available data are not enough for investigating the effect of local evaporation on the isotopic composition of regional atmosphere, we believe that we can reasonably neglect this effect and that the associated uncertainty is likely lower than the uncertainty associated with the isotopic composition of regional atmosphere.

According to the system of Eq. (1), E, T, and $I$ are undistinguishable in the water mass balance but they are separated in the chemical and stable isotope mass balances. Denoting ETI the sum of evaporation, transpiration, and infiltration, the exporting fraction of salts is defined as $F_{\mathrm{I}}=I /$ ETI and the fractionating fraction is $F_{\mathrm{E}}=E /$ ETI. The equation can thus be rewritten as follows:

$$
\begin{aligned}
& \frac{\Delta V_{\mathrm{L}}}{\Delta t}=\left(S_{\mathrm{L}} \times[P-\mathrm{ETI}]+Q_{\text {in }}\right)_{t-\Delta t} \\
& \frac{\Delta\left(V_{\mathrm{L}} \cdot C_{\mathrm{L}}\right)}{\Delta t}=\left(S_{\mathrm{L}} \times\left[P \cdot C_{\mathrm{P}}-F_{\mathrm{I}} \cdot \mathrm{ETI} \cdot C_{\mathrm{L}}\right]\right. \\
& \left.+Q_{\text {in }} \cdot C_{\text {in }}\right)_{t-\Delta t} \\
& \frac{\Delta\left(V_{\mathrm{L}} \cdot \delta_{\mathrm{L}}\right)}{\Delta t}=\left(S_{\mathrm{L}} \times\left[P \cdot \delta_{\mathrm{P}}-\left(1-F_{\mathrm{E}} \cdot \mathrm{ETI}\right) \cdot \delta_{\mathrm{L}}-\right.\right. \\
& \left.\left.F_{\mathrm{E}} \cdot \mathrm{ETI} \cdot \delta_{\mathrm{E}}\right]+Q_{\text {in }} \cdot \delta_{\text {in }}\right)_{t-\Delta t} .
\end{aligned}
$$

According to the system of Eq. (4), ETI can be determined from the water mass balance, the exporting salt fraction $\left(F_{\mathrm{I}}\right)$, i.e. infiltration from the chemical mass balance, and the fractionating fraction $\left(F_{\mathrm{E}}\right)$, i.e. evaporation from the stable isotope mass balance. Transpiration can be deduced from 
$1-\left(F_{\mathrm{I}}+F_{\mathrm{E}}\right)$. Therefore, our approach combining water, salt, and isotope mass balances is a way to formally separate evaporation, infiltration, and transpiration occurring at the surface of the lake.

Based on a deterministic calibration of the lake model, Bader et al. (2011) quantified infiltration out of Lake Chad using a forcing value of evaporation corresponding to measurements. However, the estimated infiltration lies within the range of evaporation uncertainty $(10 \%)$. Hence, a small error on the evaporation value introduced in the model will have a major impact on the calibrated infiltration. Moreover, despite the density of the vegetation cover in some areas of Lake Chad, the contribution of plant transpiration to the water and salt balances of the lake was suggested (Lemoalle, 1979) but never quantified to our knowledge. Our alternative approach proposes the following improvements:

- An evaluation of the uncertainties associated with input variables and modelling, an important issue widely discussed in the literature (Beven, 2006).

- An integration of water, chemical, and isotopic mass balances in order to better constrain poorly known terms of the lake water balance such as the respective contributions of evaporation, transpiration, and infiltration to the lake water budget. We thus propose to go one step further by using all the geochemical data available since 1950 in our approach combining water, salt, and isotope mass balances.

For these reasons, the approach detailed above for a single pool was applied to the three connected pools conceptualization of Lake Chad (Bader et al., 2011). Water balances were calculated at a daily time step and total outflows (ETI) were obtained from a Bayesian inversion of lake levels. Chemical and isotopic mass balances were then calculated at a daily time step using the parameters resulting from the inversion. The $F_{\mathrm{I}}$ and $F_{\mathrm{E}}$ parameters were subsequently calibrated at each pool from the comparison between observed and simulated chemical and isotopic values. Details are presented in Sect. 5. According to Eqs. (1)-(4), this modelling approach requires some input data $\left(Q_{\mathrm{in}}, C_{\mathrm{in}}, \delta_{\mathrm{in}}, P, C_{\mathrm{P}}, \delta_{\mathrm{P}}, \delta_{\mathrm{A}}, h\right)$ as well as some calibration-validation data for comparison with simulation outputs $\left(h_{\mathrm{L}}, C_{\mathrm{L}}, \delta_{\mathrm{L}}\right)$. The model is built at a daily timescale because it is the appropriate time step to avoid numerical oscillations of the water balance. However the results of the water, isotope, and chemical mass balances are further evaluated and discussed at seasonal and annual timescales.

\section{Hydrological, climatic, and geochemical data}

Our study is based on available hydrological, chemical, and isotopic data and some additional data acquired in this study on the LCB. References and details on the data used are provided in Supplement. A particular focus of the study was the assessment of the reliability and the quantification of uncertainties of this heterogeneous data set.

\subsection{Ground-based and altimetric lake-level data}

The lake level was monitored non-continuously from 1956 to 2008 at three gauges, in Bol (archipelagos), Kalom and Kirenowa (southern pool), and Nguigmi (northern pool); see Fig. 1 for locations (Bader et al., 2011; Lemoalle, 2004; Olivry et al., 1996). The Bol station, located in the archipelagos, provides the most complete record on a daily timescale. The other stations provide sparse observations. The data set comprises 885 lake-level data measured in the archipelagos, 150 in the southern pool and 97 in the northern pool over the 1956-2008 period. In addition, lake surface estimates in the northern pool were obtained from remote sensing (Leblanc, 2002; Leblanc et al., 2011; Lemoalle et al., 2012) and, in this study, converted into lake levels using the surface-level relationships provided by Bader et al. (2011).

\subsection{Lake Chad chemical and isotopic data}

Data from Carmouze (1976), Chantraine and Lemoalle (1976a), Chantraine and Lemoalle (1976b), Chantraine (1977), Chantraine (1978), Gac (1980), Gaultier (2004), Lemoalle (1979), Maglione (1976), Roche (1980), and Zairi (2008) were collected and completed by new samplings performed between 2008 and 2012. Due to its endorheism and climate characteristics, the lake is expected to be a concentrated basin of dissolved salts. However, the water salinity is low and relatively time constant. Exhaustive studies carried out by Carmouze (1976) on the whole lake during its normal state, between 1968 and 1971, provide a description of its geochemical features. These data show a global trend of increasing concentrations from the Chari-Logone delta $\left(\sigma=50 \mu \mathrm{S} \mathrm{cm}^{-1}\right)$ to the northern pool $\left(\sigma=1000 \mu \mathrm{S} \mathrm{cm}^{-1}\right)$ and to a lower extent to the archipelagos $\left(\sigma=600 \mu \mathrm{S} \mathrm{cm}^{-1}\right)$. The Lake Chad waters are dominated by $\mathrm{HCO}_{3}^{-}$while $\mathrm{Cl}^{-}$ and $\mathrm{SO}_{4}^{2-}$ accounts for only $2 \%$ of the anionic balance with chlorine concentrations below $1 \mathrm{mg} \mathrm{L}^{-1}$. Calcium is the most abundant cation near the Chari-Logone mouth, while sodium becomes dominant in more concentrated waters because it does not react with the lake substratum or the vegetation (Carmouze, 1976). Therefore, sodium and chlorine can be considered conservative elements except in the northern margin where limited deposits of natron $\left(\mathrm{Na}_{2} \mathrm{CO}_{3}\right)$ are described. However, because of the low chlorine content in the waters, very few accurate chlorine measurements are available. Hence, only sodium is considered a conservative element in this study. Sodium concentrations in the lake during the normal state were about $0.3 \mathrm{mmolL}^{-1}$ in the southern pool, $2 \mathrm{mmol} \mathrm{L}^{-1}$ in the northern pool and $0.5 \mathrm{mmol} \mathrm{L}^{-1}$ in the archipelagos (Fig. 2).

Four extensive spatial studies were carried out in 1969 for stable isotopes (Roche, 1980). They confirmed the spa- 

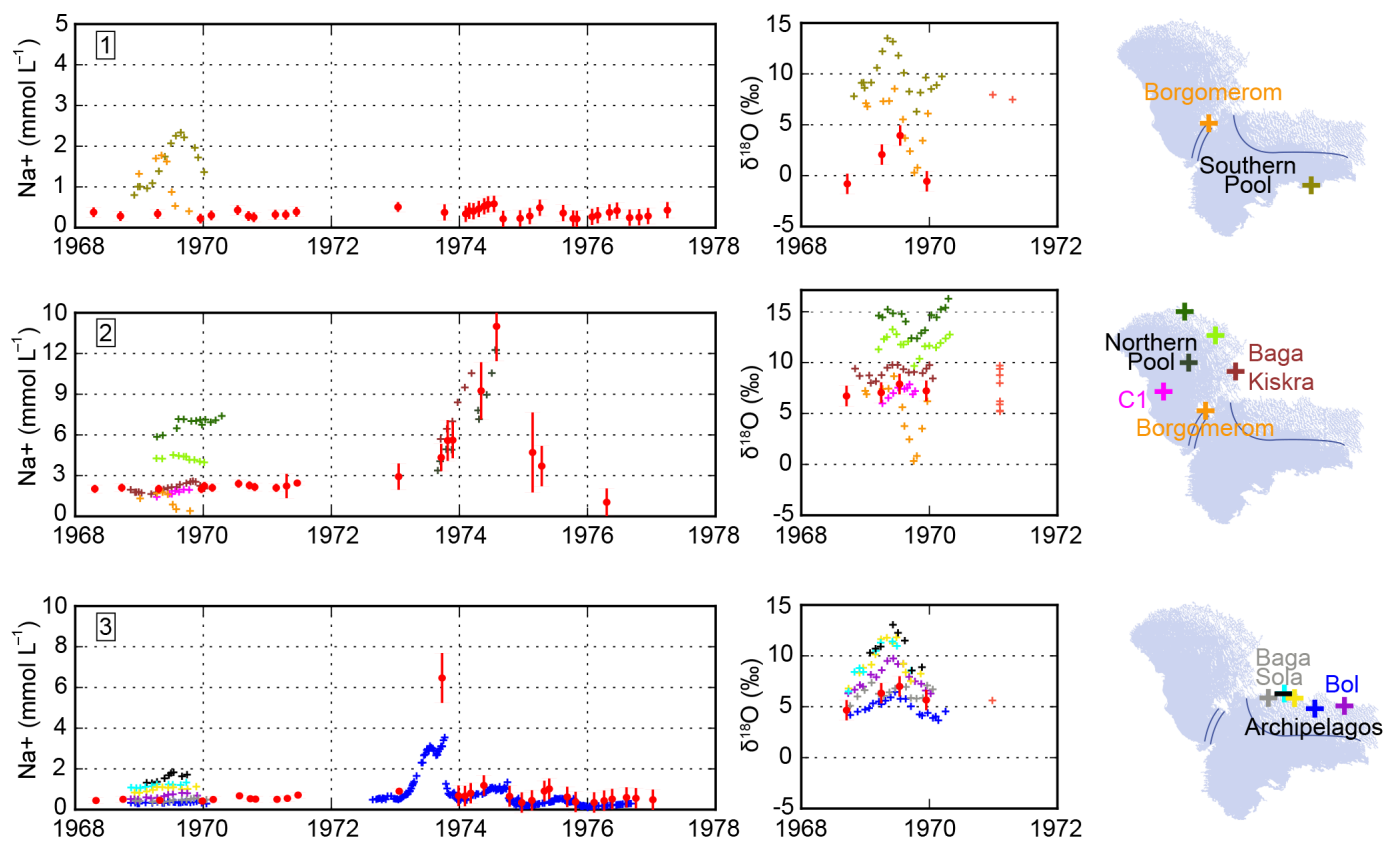

Figure 2. Sodium concentration and $\delta^{18} \mathrm{O}$ isotopic composition of Lake Chad water over the 1968-1978 time period in (1) the southern pool, (2) the northern pool, (3) the archipelagos. Red dots are mean values with their $1 \sigma$ uncertainties (calculated from spatially distributed sampling campaigns) and cross-symbols are local measurements, whose localization is shown by a same-coloured cross-symbol on the Lake Chad map on the right.

tial distribution shown by the chemical concentrations: waters are more enriched as they flow away from the Chari mouth $\left(\delta^{18} \mathrm{O} \sim 2 \%\right.$ o $)$ to the northern pool $\left(\delta^{18} \mathrm{O} \sim 10 \%\right.$ o). The oxygen and hydrogen isotopic composition of all available lake water measurements plot along an evaporation line of $\delta^{2} \mathrm{H}=5.2 \times \delta^{18} \mathrm{O}+1$ (Fontes et al., 1970a) and $\delta^{2} \mathrm{H}=4.4( \pm 0.2) \times \delta^{18} \mathrm{O}+2.82( \pm 1.12)$ (Gaultier, 2004). Apart from extensive spatial studies, the seasonal monitoring of sodium concentrations and oxygen isotope data at local stations illustrate the spatial and temporal variability of geochemical data in the lake (Fig. 2) (Fontes et al., 1970a; Roche, 1980). Most studies have been carried out on Lake Chad in its normal state. Although punctual in space and time, a few recent studies (Gaultier, 2004; Zairi, 2008, this study) provide valuable data on Lake Chad in its small state.

\subsection{River data}

The Chari-Logone discharges were reconstructed from river height measurements at the gauging station of N'Djamena. The Komadougou Yobe and El Beid discharges were calculated from observations and correlations with the ChariLogone discharge (Bader et al., 2011). These discharges were considered for a period between 1956 and 2011. Uncertainties, which could depend on installations, reading, gauging station calibration curve, and reconstructions of the data set, were evaluated at a reasonable value of $10-15 \%$ (Cogley, 1989).
The sodium concentrations and the isotopic compositions of the Chari-Logone and Komadougou Yobe rivers were measured near their mouth between 1956 and 2009 (Carmouze, 1976; Djoret, 2000; Gac, 1980; Olivry et al., 1996; Roche, 1969; Zairi, 2008). We completed these data sets by new data, from samples collected between 2008 and 2013.

The Komadougou Yobe River is characteristic of more arid climatic conditions with concentrations in $\mathrm{Na}^{+}$between 0.2 and $0.5 \mathrm{mmolL}^{-1}$ against $0.1-0.2 \mathrm{mmol} \mathrm{L}^{-1}$ in the ChariLogone and oxygen isotopic compositions between -4 and $+8 \%$ in the Komadougou Yobe against -6 and $+3 \%$ in the Chari-Logone. Both $\left[\mathrm{Na}^{+}\right]$and $\delta^{18} \mathrm{O}$ evidenced a high seasonality for the two rivers with minima recorded during high-water levels at the end of the humid season (September) and maxima recorded during the dry season (April-May). The long-term-weighted average isotopic composition of the Chari Logone is $-3 \%$ ofor $\delta^{18} \mathrm{O}$ and $-20 \%$ ofor $\delta^{2} \mathrm{H}$. The interannual variability of concentrations and isotopic compositions in rivers is low and there is no significant change in the water composition of the rivers between the normal and small states of the lake (Fig. 3).

\subsection{Rainfall data}

In this study, we used the rainfall data set reconstructed by Bader et al. (2011) from precipitation measurements at five stations around Lake Chad. Sodium concentrations in rainfall were measured at a monthly time step by Roche (1980) 

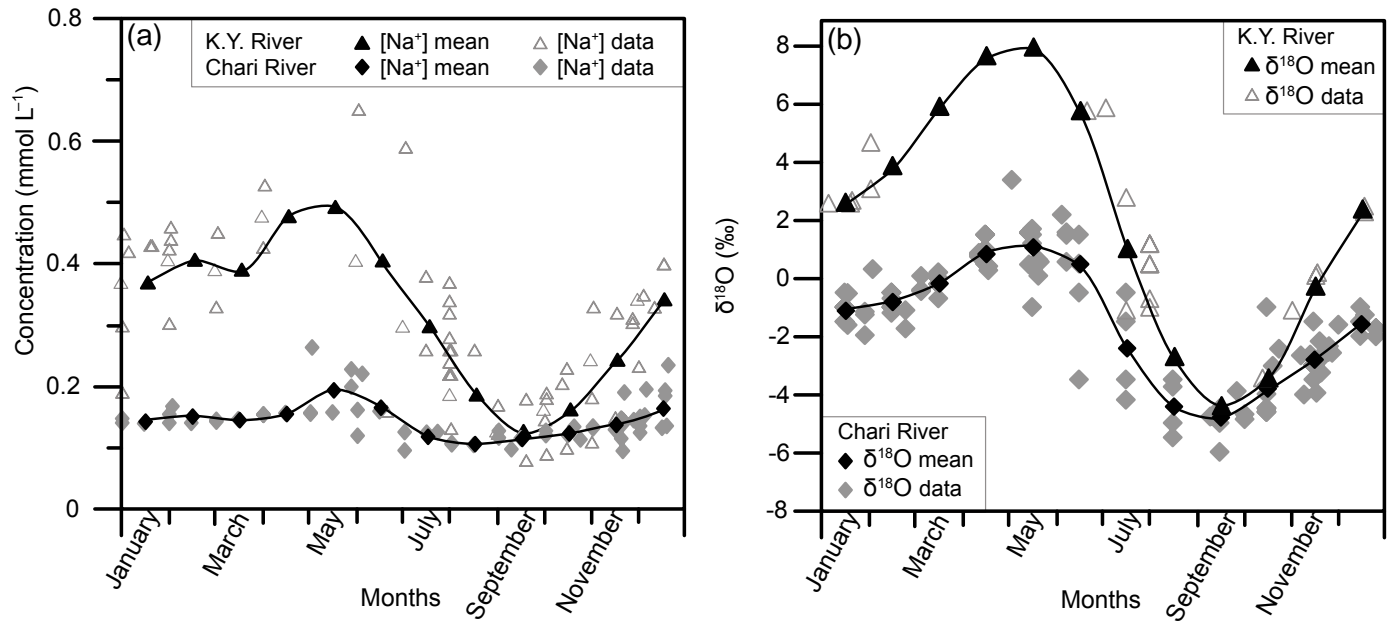

Figure 3. River input variables (a) sodium concentrations in the Chari-Logone and Komadougou Yobe (KY): measured sodium concentrations in the Komadougou Yobe (triangles); mean annual scenario of sodium concentration reconstructed for the KY (black line with plain triangles); measured concentrations in the Chari-Logone (grey diamonds); mean annual scenario of sodium concentration reconstructed for the Chari-Logone (black line with plain diamonds). (b) Oxygen-18 composition in the Chari-Logone and Komadougou Yobe (KY): measured $\delta^{18} \mathrm{O}$ in the Komadougou Yobe (triangles); mean annual scenario of $\delta^{18} \mathrm{O}$ reconstructed for the $\mathrm{KY}$ (black line with plain triangles); measured $\delta^{18} \mathrm{O}$ in the Chari-Logone (grey diamonds); mean annual scenario of $\delta^{18} \mathrm{O}$ reconstructed for the Chari-Logone (black line with plain diamonds).

in 1969. They range between 0.05 and $0.24 \mathrm{mmol} \mathrm{L}^{-1}$. Concentrations around $1 \mathrm{mmol} \mathrm{L}^{-1}$ were measured in rainfall in Nigeria (Goni et al., 2001) but are higher than the concentrations of river and lake samples. These questionable values were thus not considered in this study.

In all, 86 non-continuous measurements of deuterium and oxygen isotopes in precipitation (Fig. 4) were carried out between 1964 and 1995 at N'Djamena by the GNIP (Global Network for Isotopes in Precipitation; http://www.iaea.org/ water). The measurements at N'Djamena define the local meteoritic line: $\delta^{2} \mathrm{H}=6.3 \times \delta^{18} \mathrm{O}+4.3\left(r^{2}=0.95\right)$ with longterm-weighted averages and standard deviations of $-3.8 \pm$ $1.7 \%$ for $\delta^{18} \mathrm{O}$ and $-18 \pm 10 \%$ for $\delta^{2} \mathrm{H}$. The low slope of the local meteoritic line is in agreement with measurements throughout the Sahelian band and indicates that enriched precipitations are probably affected by evaporation in the atmosphere (Gallaire, 1995; Goni et al., 2001).

\subsection{Atmospheric vapour isotopic data, air temperature, and relative humidity}

The isotopic composition of atmospheric vapour is rarely measured and the usual assumption of an isotopic equilibrium with rainfall is highly questionable in climates with long dry periods (Vallet-Coulomb et al., 2008). A few vapour measurements were performed in 1969 using the cryogenic trapping method (Fontes et al., 1970a), but because of their scarcity, and of the sampling conditions, they can only be considered as a rough indication of the order of magnitude (Fig. 4). Recently, a detailed annual record of $\delta^{18} \mathrm{O}$ of water vapour was performed by using laser spectrometry at $\mathrm{Ni}$ -

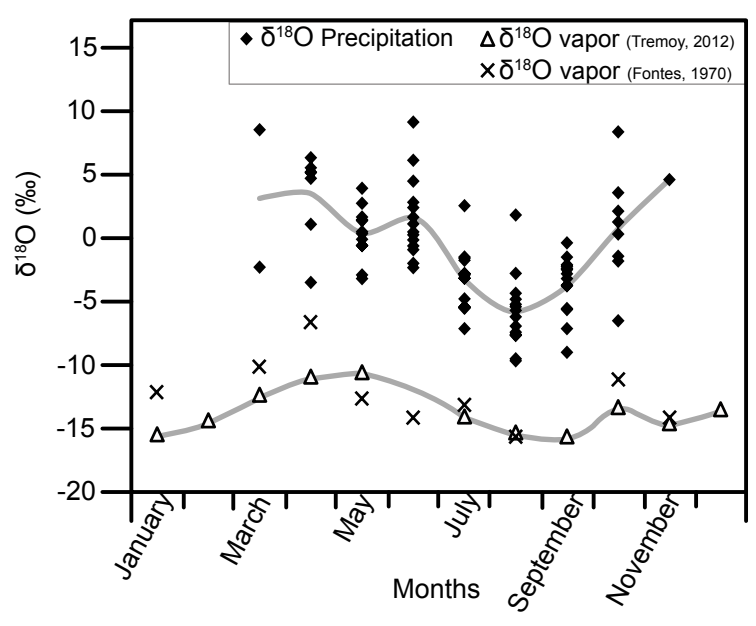

Figure 4. Isotopic composition of precipitations (black diamonds, data from GNIP, IAEA), and regional atmospheric vapour measured by Tremoy et al. (2012), triangles, and by Fontes et al. (1970a), black crosses. The grey lines represent the mean annual scenarios.

amey, Niger (Tremoy et al., 2012) (Fig. 4). It is the only available record in the Sahelian band, and we assume that it can be used as a record of the seasonal isotopic variations in the Lake Chad region, since both areas are under the same climatic conditions. This assumption will be further discussed through sensitivity analysis.

Mean monthly data of air temperature and relative humidity were obtained from the Climatic Research Unit (Harris et al., 2014) $0.5^{\circ} \times 0.5^{\circ}$ data set. Air temperature 
reaches a maximum in May $\left(30^{\circ} \mathrm{C}\right)$ and a minimum in January $\left(20^{\circ} \mathrm{C}\right)$ and relative humidity reaches a maximum in August $(70 \%)$ and a minimum in March $(20 \%)$. The amplitude of variation and the low values of humidity are consistent with the relative humidity measurements at N'Djamena (Olivry et al., 1996). We assume that the lake temperature is similar to air temperature because the lake is shallow, well mixed by the wind and seasonal variations of air temperature in central Sahel remain low.

\subsection{Evaporation}

Evaporation above Lake Chad was estimated by several methods. Measurements from lysimeters provide the most reliable data while measurements by evaporimeter or evaporation pans lead to different estimations (Monteith, 1991; Olivry et al., 1996; Riou and Dubois, 1967). Lysimeter measurements at Bol (archipelagos) between 1965 and 1977 gave an average annual evaporation rate of $2170 \mathrm{~mm} \mathrm{yr}^{-1}$, a maximum during the dry season in April $\left(229 \mathrm{~mm} \mathrm{month}^{-1}\right)$, another one in October $\left(199 \mathrm{~mm} \mathrm{month}^{-1}\right)$, and a minimum in January $\left(136 \mathrm{~mm} \mathrm{month}^{-1}\right)$. The potential evapotranspiration rates obtained from reanalysis by the Climatic Research Unit (CRU) from 1900 to 2012 lead to a total annual evaporation of $2022 \mathrm{~mm} \mathrm{yr}^{-1}$ in the southern pool, $1952 \mathrm{~mm} \mathrm{yr}^{-1}$ in the archipelagos, and $2365 \mathrm{~mm} \mathrm{yr}^{-1}$ in the northern pool.

The different estimates remain within a $10 \%$ error range, consistently with other studies (Rosenberry et al., 2007; Vallet-Coulomb et al., 2001), and the seasonality, the interannual variability, and the spatial variability were found to be similar whatever the method used. The seasonality shown by the lysimeter measurements is significant and reveals the same pattern as the CRU data. The interannual variability of the total evaporation is less than $10 \%$ (Olivry et al., 1996) and the standard deviation on the CRU evaporation over the whole period is less than $2 \%$ for all pools (with a maximum in 2009 of $2100 \mathrm{~mm} \mathrm{yr}^{-1}$ in the southern pool and a minimum in 1961 of $1941 \mathrm{~mm} \mathrm{yr}^{-1}$ ). Moreover, no significant change during the climatic transition period was observed. Finally, both methods show that evaporation rates are almost similar in the southern pool and in the archipelagos and $10 \%$ higher in the northern pool.

\section{Methodology}

\subsection{Conceptualization of Lake Chad (from Bader et al. 2011)}

Different lake water balance models were previously implemented to simulate the Lake Chad level fluctuations (Vuillaume, 1981; Olivry et al., 1996). The conceptualization of the lake of Bader et al. (2011) comprises three interconnected pools and allows a more reliable and realistic description of the Lake Chad system. The model is exhaustively described in Bader et al. (2011) and has the follow- ing main features. The lake is represented by three pools: the northern pool, the southern pool, and the archipelagos (Fig. 1). The southern and northern pools on the one hand, and the southern pool and archipelagos on the other hand, are connected by channels. In these channels, water flows are expressed according to the Manning-Strickler equation. The Manning-Strickler parameter is a function of the channel roughness but because of growing vegetation during low water stages in Lake Chad, this parameter is directly related to the water level in the channel. Consequently, a linear regression between the Manning-Strickler parameter and the water level is considered, with $\mathrm{A} 0\left(\mathrm{~m}^{5 / 6} \mathrm{~s}^{-1}\right)$ being the intercept and $\mathrm{A} 1\left(\mathrm{~m}^{-1 / 6} \mathrm{~s}^{-1}\right)$ the slope of the regression. Therefore, the Manning-Strickler equation can be written as $Q=0.0864(\mathrm{AO}+\mathrm{A} 1 \times \mathrm{ZC}) \times \mathrm{ZC}^{5 / 3} \times D^{1 / 2}$, where $\mathrm{ZC}(\mathrm{m})$ is the lake level in the channel, $D(\mathrm{~m})$ the lake-level difference between two pools, and 0.0864 a scaling factor.

The two parameter sets are denoted $\left(\mathrm{A} 0_{\mathrm{SA}}, \mathrm{A} 1_{\mathrm{SA}}\right)$ and $\left(\mathrm{A} 0_{\mathrm{SN}}, \mathrm{A} 1_{\mathrm{SN}}\right)$ for the channels between the southern pool and the archipelagos and the southern pool and the northern pool, respectively. Parameterization of the northern pool water budget also involves a soil reservoir, whose depth, denoted as $Z_{R}(\mathrm{~m})$, is an unknown parameter of the model. This parameter is essential to account for the presence of water in the soil porosity when the northern pool dries up. Compared to the one-pool conceptual model of Sect. 3, five additional parameters $\left(\mathrm{A} 0_{\mathrm{SA}}, \mathrm{A} 1_{\mathrm{SA}}, \mathrm{A} 0_{\mathrm{SN}}, \mathrm{A} 1_{\mathrm{SN}}, Z_{\mathrm{R}}\right)$ are thus introduced.

The surface-lake-level relationships in the southern and northern pools were obtained from bathymetric surveys. The surface of the archipelagos is considered to cover one-fourth of the surface of the southern pool and its surface-lake-level relationship includes one unknown parameter calibrated by Bader et al. (2011) and is kept unchanged in this study.

\subsection{Direct model for the water, chemical, and isotopic lake balance in the three connected pools}

\subsubsection{Mathematical description of the water balance}

The water balance was calculated in each pool according to the following equations:

$$
\begin{aligned}
& \frac{\Delta V_{\mathrm{S}}}{\Delta t}=\left(\mathrm{S}_{\mathrm{S}} \times\left(P_{\mathrm{S}}-\mathrm{ETI}_{\mathrm{S}}\right)+Q_{\mathrm{Chari}}-Q_{\mathrm{SN}}-Q_{\mathrm{SA}}\right)_{t-\Delta t} \\
& \frac{\Delta V_{\mathrm{A}}}{\Delta t}=\left(\mathrm{S}_{\mathrm{A}} \times\left(P_{\mathrm{A}}-\mathrm{ETI}_{\mathrm{A}}\right)+Q_{\mathrm{SA}}-\mathrm{QF}\right)_{t-\Delta t} \\
& \frac{\Delta W_{\mathrm{N}}}{\Delta t}=\left(\mathrm{ST}_{\mathrm{N}} \times\left(P_{\mathrm{N}}-\mathrm{ETI}_{\mathrm{N}}\right)+Q_{\mathrm{KY}}+Q_{\mathrm{SN}}\right)_{t-\Delta t} \\
& W_{\mathrm{N}}=V_{\mathrm{N}}\left[H_{\mathrm{N}}+Z_{\mathrm{R}}\right] ; \mathrm{ST}_{\mathrm{N}}=\mathrm{S}_{\mathrm{N}}\left[H_{\mathrm{N}}+Z_{\mathrm{R}}\right] \\
& Q_{\mathrm{SA}}=0.0864 \times\left(A 0_{\mathrm{SA}}+\mathrm{A} 1_{\mathrm{SA}} \times \mathrm{ZC}_{\mathrm{SA}}\right) \times \mathrm{ZC}_{\mathrm{SA}}^{5 / 3} \times D_{\mathrm{SA}}^{1 / 2} \\
& Q_{\mathrm{SN}}=0.0864 \times\left(A 0_{\mathrm{SN}}+\mathrm{A} 1_{\mathrm{SN}} \times \mathrm{ZC}_{\mathrm{SN}}\right) \times \mathrm{ZC}_{\mathrm{SN}}^{5 / 3} \times D_{\mathrm{SN}}^{1 / 2},
\end{aligned}
$$

where $V$ is the volume, $S$ the surface, $P$ the rainfall, ETI the total water losses, and $Q$ the discharges. $W$ the volume 
and ST the surface are specifically defined to take into account the soil in the northern pool. The subscripts $\mathrm{S}, \mathrm{A}$, and $\mathrm{N}$ refer to the southern pool, the archipelagos and the northern pool respectively. $Q_{\text {Chari }}$ and $Q_{\mathrm{KY}}$ are the input flows of the Chari-Logone and the Komadougou Yobe, respectively. $\mathrm{QF}$ is the outflow of the lake into the Bahr el Ghazal when the lake level exceeds $282.3 \mathrm{~m}$ (Fig. 1). $Q_{\mathrm{SA}}$ and $Q_{\mathrm{SN}}$ stands for the flows between the southern pool and the archipelagos and between the southern pool and the northern pool, respectively, according to the Manning-Strickler equation. These equations are solved by a finite difference approach on a daily time step; i.e. $\Delta t=1$ day. The area and lake levels of the pools were then obtained from the calculated volume using the relationship between surface and level previously established by Bader et al. (2011).

\subsubsection{Mathematical description of a conservative element and isotopic composition mass balances}

The concentration of a conservative element (Eq. 6) and the isotopic composition of lake water (Eq. 7), whether for the hydrogen or the oxygen isotopes, within the three pools were calculated using the following equations:

$$
\begin{aligned}
& \frac{\Delta\left(V_{\mathrm{S}} \cdot C_{\mathrm{S}}\right)}{\Delta t}=\left(\mathrm{S}_{\mathrm{S}} \cdot\left[P_{\mathrm{S}} \cdot C_{\mathrm{P}}-F_{\mathrm{I}_{\mathrm{S}}} \cdot \mathrm{ETI}_{\mathrm{S}} \cdot C_{\mathrm{S}}\right]\right. \\
& \left.+Q_{\mathrm{Chari}} \cdot C_{\mathrm{Chari}}-Q_{\mathrm{SN}} \cdot C_{\mathrm{S} / \mathrm{N}}-Q_{\mathrm{SA}} \cdot C_{\mathrm{S} / \mathrm{A}}\right)_{t-\Delta t} \\
& \frac{\Delta\left(V_{\mathrm{A}} \cdot C_{\mathrm{A}}\right)}{\Delta t}=\left(\mathrm{S}_{\mathrm{A}} \cdot\left[P_{\mathrm{A}} \cdot C_{\mathrm{P}}-F_{\mathrm{I}_{\mathrm{A}}} \cdot \mathrm{ETI}_{\mathrm{A}} \cdot C_{\mathrm{A}}\right]\right. \\
& \left.+Q_{\mathrm{SA}} \cdot C_{\mathrm{S} / \mathrm{A}}-\mathrm{QF} \cdot C_{\mathrm{A}}\right)_{t-\Delta t} \\
& \frac{\Delta\left(W_{\mathrm{N}} \cdot C_{\mathrm{N}}\right)}{\Delta t}=\left(\mathrm{ST} \mathrm{S}_{\mathrm{N}} \cdot\left[P_{\mathrm{N}} \cdot C_{\mathrm{P}}-F_{\mathrm{I}_{\mathrm{N}}} \cdot \mathrm{ETI}_{\mathrm{N}} \cdot C_{\mathrm{N}}\right]\right. \\
& \left.+Q_{\mathrm{KY}} \cdot C_{\mathrm{KY}}+Q_{\mathrm{SN}} \cdot C_{\mathrm{S} / \mathrm{N}}\right)_{t-\Delta t}, \\
& \frac{\Delta\left(V_{\mathrm{S}} \cdot \delta_{\mathrm{S}}\right)}{\Delta t}=\left(\mathrm { S } _ { \mathrm { S } } \cdot \left[P_{\mathrm{S}} \cdot \delta_{\mathrm{P}}-\left(1-F_{\mathrm{E}_{\mathrm{S}}}\right) \cdot \mathrm{ETI}_{\mathrm{S}} \cdot \delta_{\mathrm{S}}-F_{\mathrm{E}_{\mathrm{S}}}\right.\right. \\
& \left.\left.\cdot \mathrm{ETI}_{\mathrm{S}} \cdot \delta_{\mathrm{ES}}\right]+Q_{\mathrm{Chari}} \cdot \delta_{\mathrm{Chari}}-Q_{\mathrm{SN}} \cdot \delta_{\mathrm{S} / \mathrm{N}}-Q_{\mathrm{SA}} \cdot \delta_{\mathrm{S} / \mathrm{A}}\right)_{t-\Delta t} \\
& \frac{\Delta\left(V_{\mathrm{A}} \cdot \delta_{\mathrm{A}}\right)}{\Delta t}=\left(\mathrm { S } _ { \mathrm { A } } \cdot \left[P_{\mathrm{A}} \cdot \delta_{\mathrm{P}}-\left(1-F_{\mathrm{E}_{\mathrm{A}}}\right) \cdot \mathrm{ETI}_{\mathrm{A}} \cdot \delta_{\mathrm{A}}-\right.\right. \\
& \left.\left.F_{\mathrm{E}_{\mathrm{A}}} \cdot \mathrm{ETI}_{\mathrm{A}} \cdot \delta_{\mathrm{EA}}\right]+Q_{\mathrm{SA}} \cdot \delta_{\mathrm{S} / \mathrm{A}}-Q F \cdot \delta_{\mathrm{A}}\right)_{t-\Delta t} \\
& \frac{\Delta\left(W_{\mathrm{N}} \cdot \delta_{\mathrm{N}}\right)}{\Delta t}=\left(\mathrm { ST } _ { \mathrm { N } } \cdot \left[P_{\mathrm{N}} \cdot \delta_{\mathrm{P}}-\left(1-F_{\mathrm{E}_{\mathrm{N}}}\right) \cdot \mathrm{ETI}_{\mathrm{A}} \cdot\right.\right. \\
& \left.\left.\delta_{\mathrm{N}}-F_{\mathrm{E}_{\mathrm{N}}} \cdot \mathrm{ETI}_{\mathrm{N}} \cdot \delta_{\mathrm{EN}}\right]+Q_{\mathrm{KY}} \cdot \delta_{\mathrm{KY}}+Q_{\mathrm{SN}} \cdot \delta_{\mathrm{S} / \mathrm{N}}\right)_{t-\Delta t},
\end{aligned}
$$

where $C_{\mathrm{Chari}}, C_{\mathrm{KY}}, C_{\mathrm{P}}, \delta_{\mathrm{Chari}}, \delta_{\mathrm{KY}}, \delta_{\mathrm{P}}$ are the measured concentrations and isotopic compositions in the Chari-Logone River, in the Komadougou Yobe River and in the rainfall. $C_{\mathrm{S}}$, $C_{\mathrm{A}}, C_{\mathrm{N}}, \delta_{\mathrm{S}}, \delta_{\mathrm{A}}, \delta_{\mathrm{N}}$ represent the simulated concentrations of a conservative element and isotopic composition in the southern pool, in the archipelagos, and in the northern pool. $C_{\mathrm{S} / \mathrm{A}}$, $C_{\mathrm{S} / \mathrm{N}}, \delta_{\mathrm{S} / \mathrm{A}}, \delta_{\mathrm{S} / \mathrm{N}}$ refer to the concentrations and isotopic compositions of the flows between two pools and their values depend on the flow directions. If water flows from the southern pool to the archipelagos, then $C_{\mathrm{S} / \mathrm{A}}=C_{\mathrm{S}}$ and $\delta_{\mathrm{S} / \mathrm{A}}=\delta_{\mathrm{S}}$, and if waters flow from the archipelagos to the southern pool, then $C_{\mathrm{S} / \mathrm{A}}=C_{\mathrm{A}}$ and $\delta_{\mathrm{S} / \mathrm{A}}=\delta_{\mathrm{A}}$. The isotopic composition of the evaporated moisture above each lake pool was calculated from Craig and Gordon (1965). A threshold of sodium concentration was added corresponding to the solubility of natron $\left(\mathrm{Na}_{2} \mathrm{CO}_{3}\right)$ during the drying episodes that occurred in the archipelagos and in the northern pool followed by the deposition of natron evaporites. We consider that salts are removed from the lake system, following previous assumptions of a rapid removal by re-dissolution of salts by rainfall and infiltration into the Quaternary aquifer or by exportation by winds (Fontes et al., 1969). Lake Chad is a fresh water lake with salinity below $1 \mathrm{~g} \mathrm{~L}^{-1}$ while salinity has effects on fractionation when concentrations exceed those of seawater (Gat, 1996). In our model, we neglected this aspect as high concentrations are only simulated during episodes of drying of the Archipelagos that account for less than $1 \%$ of the whole time period. Although the isotopic model is probably too rough during these episodes, we did not focus on this extreme situation, neither in terms of results nor in the discussion, as we do not have data to constrain it.

\subsubsection{Data processing to obtain daily input variables for the model}

The means of available punctual measurements for each month were used to estimate monthly average sodium and isotopic compositions of rivers. The yearly seasonal cycles, shown by the monthly average values, were interpolated to daily values by a spline interpolation and repeatedly applied every year (Figs. 3 and 4), from 1956 to 2011. The only yearly seasonal cycles available of sodium concentrations in rainfall and isotopic compositions of vapour were similarly interpolated to daily values by a spline interpolation and repeatedly applied every year (Figs. 3 and 4).

Temperature and relative humidity data are available on a monthly time step for the entire 1956-2011 time period. The isotopic compositions of rainfall are available on a monthly time step between 1964 and 1978 and missing monthly values were reconstructed using the average of the considered month. Daily inputs of $T, h$, and $\delta$ P between 1956 and 2011 were obtained by a spline interpolation.

In addition, continuous daily records of rainfall and water flows were used.

\subsubsection{Estimation of ETI at a daily time step}

Although the final inverted parameters are the annual values of ETI in the three pools, the model requires the introduction of daily values of ETI. For this purpose and because evaporation is the prominent flux of ETI, the annual ETI values were distributed at a daily time step in the model, following the seasonal variability of evaporation. 


\subsection{Model parameters inversion}

\subsubsection{ETI inversion from a Metropolis algorithm applied on lake-level simulations}

Eight parameters are involved in the direct water balance model (Eq. 5): $Z_{\mathrm{R}}, \mathrm{A} \mathrm{A} 0_{\mathrm{SA}}, \mathrm{A} 1_{\mathrm{SA}}, \mathrm{A} 0_{\mathrm{SN}}$ and $\mathrm{A} 1_{\mathrm{SN}}, \mathrm{ETI} \mathrm{S}_{\mathrm{S}}$, $\mathrm{ETI}_{\mathrm{N}}, \mathrm{ETI}_{\mathrm{A}}$. Let us denote $\boldsymbol{m}(\mathrm{m} 1, \ldots, \mathrm{m} 8)$ the vector of the eight parameters. Since 1237 measured lake-levels are available, the system is over constrained. Probabilistic inversion approaches lead to a better description of parameters through a posteriori probability density functions (PDF) instead of one single deterministic value for each parameter. Basically, these probabilistic inverse methods consist in a Monte Carlo calculation that is a random and oriented exploration of the parameter space and an identification of the parameter sets yielding the best simulations through direct model-data comparisons (Eq. 8). The result of this guided random walk using a priori PDF for each parameter is a collection of parameter sets that satisfactorily reproduce the observations allowing for the identification of a posteriori PDF for each parameter. Monte Carlo Markov chain (MCMC) inversion is widely used in hydrological studies (Dotto et al., 2011; Jeremiah et al., 2012; Kuczera and Parent, 1998; Marshall et al., 2004) and for lake modelling (Lesht et al., 1991).

Each parameter is defined by a consistent a priori probability density function, $\rho(\boldsymbol{m})$. Uniform laws bounded by realistic values of parameters were considered. The soil reservoir $\left(Z_{R}\right)$ reflects the part of the underlying aquifer directly in connection with the lake and is bounded between 0 and $5 \mathrm{~m}$ depth according to realistic evaporative rates. Upper and lower bounds of 0 and 1000, and -500 and 500 were considered for A0 and A1, respectively. Because ETI are dominated by evaporation and evaporation is higher in the northern pool, two conditions were added to satisfy the observed climatic gradient: $\mathrm{ETI}_{\mathrm{N}}>\mathrm{ETI}_{\mathrm{S}}$ and $\mathrm{ETI}_{\mathrm{A}}<\mathrm{ETI}_{\mathrm{N}}$. A value of $2000 \mathrm{~mm} \mathrm{yr}^{-1}$ (close to the evaporation value in the southern pool) was used for the ETI lower boundary in each pool while the upper bound is set at $3500 \mathrm{~mm} \mathrm{yr}^{-1}$.

The model data comparison involves a misfit function $S(\boldsymbol{m})$ between simulated and measured variables. Owing to its large popularity in the hydrological community, a misfit function derived from the Nash criterion was used to evaluate the accuracy of our hydrological modelling:

$S(\boldsymbol{m})=1-\mathrm{Na}=\frac{\sum_{i=0}^{n}\left(h_{\mathrm{obs}, i}-h_{\mathrm{sim}, i}(\boldsymbol{m})\right)^{2}}{\sum_{i=0}^{n}\left(h_{\mathrm{obs}, i}-h_{\text {mean }}\right)^{2}}$,

where $h_{\mathrm{sim}, i}$ are the simulated lake levels, $h_{\mathrm{obs}, i}$ the existing lake-level measurements (Sect. 4) and $h_{\text {mean }}$ the mean of all lake-level measurements.

The a posteriori PDF is inferred from a guided random walk generated by the Metropolis algorithm
(Mosegaard and Tarantola, 1995), which tends to reduce the error between model and data. Details are provided in the Supplement.

As pinpointed by Mosegaard and Tarantola (1995), defining the acceptance rule to achieve convergence is a nontrivial task. In our study, we considered a maximum value for the misfit of 0.06 to retain a parameter set. The Nash value of 0.94 corresponds to a systematic error of $35 \mathrm{~cm}$ and seems acceptable considering the cumulative uncertainties on the lake-level measurements and input variables.

\subsection{2 $\quad F_{\mathrm{I}}$ and $\boldsymbol{F}_{\mathrm{E}}$ calibration from geochemical simulations}

The calibration of $F_{\mathrm{I}}$ and $F_{\mathrm{E}}$ was carried out for each pool, using the ETI (mean \pm 1 standard deviation) obtained from the lake-level inversion. To do so, the fits between geochemical simulations and observations, for values of $F_{\mathrm{I}}$ and $F_{\mathrm{E}}$ between 0 and 1 , are estimated by a misfit function. The chosen misfit function is defined as the difference between chemical and isotopic observations $\left(f_{\mathrm{obs}, i}\right)$ and simulations $\left(f_{\mathrm{sim}, i}\right) \mathrm{di}$ vided by the uncertainties of the observations:

$S=\frac{1}{n} \sum_{i=0}^{n}\left(\frac{f_{\mathrm{obs}, i}-f_{\mathrm{sim}, i}}{\sigma_{f_{\mathrm{obs}, i}}}\right)^{2}$

A value lower than 1 thus indicates that the difference between simulations and observations is within the range of data uncertainties yielding acceptable values of $F_{\mathrm{I}}$ and $F_{\mathrm{E}}$.

\subsubsection{Data processing to enable $F_{\mathrm{E}}$ and $\boldsymbol{F}_{\mathrm{I}}$ calibration}

Simulated concentrations and isotopic compositions are mean values over each pool. While vertical lake water column homogeneity is observed because of the shallowness of the lake, easily mixed by winds, the horizontal lake water homogeneity is not verified in Lake Chad as described in Sect. 4. Therefore, only extensive sampling campaigns are fully representative.

From 1968 to 1971,12 monthly chemical monitoring campaigns, which collected between 50 and 200 samples, were carried out on the whole of Lake Chad (Carmouze, 1976). We calculated the mean sodium composition in each pool by a volume-weighted average of all measurements for each campaign (Fig. 2). The uncertainties associated with the mean values between 1968 and 1971 are related to measurement errors and not to the horizontal variability because of the good spatial distribution. They are thus weak and set at $0.1 \mathrm{mmolL}^{-1}$. From 1973 to 1977,23 monthly chemical monitoring campaigns were conducted (around 15 measurements per pool per study) but on a non-exhaustive lake area (Chantraine and Lemoalle, 1976a, b; Chantraine, 1977, 1978). To evaluate the bias of determining a mean composition based on a limited measurement area, we calculated the multiplying coefficients between the mean concentrations of 
this partial area and of the entire pool for the extensive studies by Carmouze (1976). In order to bypass the partial sampling issue between 1973 and 1977, the concentration means of the partial area were multiplied by these coefficients (between 1 and 2). The associated uncertainties are related to the correcting coefficient that was calculated in a normal state while 1973-1977 was a drying period. Therefore, the uncertainties of the mean values between 1973 and 1977 were calculated by the difference between the corrected and uncorrected means. Due to their large uncertainties, the sodium concentrations from 1973 to 1977 are less constraining in the parameter calibration process (see Eq. 9). However, they provide additional information on a different time period.

In April, July, September, and December 1969, extensive sampling campaigns and analysis of lake water $\delta^{18} \mathrm{O}$ compositions were conducted ( $>50$ samples; Roche, 1980). We calculated the mean $\delta^{18} \mathrm{O}$ in each pool by a volume-weighted average of all measurements for each campaign (Fig. 2). The uncertainties associated with the mean values are related to measurement errors and not to the horizontal variability because of the good spatial distribution. They are thus low and set at $1 \%$.

\subsubsection{Calibration period}

Sodium data representative of mean pool values are available for the 1968-1976 period, whereas only a 1-year record of isotopic data representative of mean pool values is available. Calibration was therefore only done during this time period, corresponding to the normal state of Lake Chad (before 1972) and the drying transition period (1972-1976). Although punctual and local, recent data enable a rough validation of the model since they give information on the lake in a small state, which is very different from the calibration period.

\section{Results}

\subsection{Estimation of the total water losses (ETI)}

\subsubsection{Convergence of the Metropolis algorithm}

The convergence of the model was obtained with 25000 iterations. Three starting sets of parameters were tested and we noticed that the choice of the starting point influences the time of convergence (i.e. the number of iterations required to achieve convergence) but not the final range of accepted parameters. This proves the robustness of the convergence. The misfit function of the Metropolis algorithm and the 0.06 threshold for $S(\boldsymbol{m})$ is shown in Supplement. A total number of 6584 parameter sets were accepted, revealing the expected equifinality issue in conceptual modelling, and fully justifying the use of a Bayesian approach.

\subsubsection{Parameter distributions, uncertainty, and correlation}

The sets of parameters leading to a misfit below 0.06 were used to establish the a posteriori distributions of the eight parameters shown in Fig. 5. The sharper the distribution is, the better constrained is the parameter. All the parameters present unimodal distributions. They are fitted by a normal curve except for the $\mathrm{A} 0_{\mathrm{SA}}$ that is fitted by a lognormal distribution. The associated mean and standard deviations are calculated and presented in Fig. 5 and Table 1. For comparison, the calibrated parameters obtained by Bader et al. (2011) are also shown in Fig. 5. While all of them fit into the range of acceptable parameters that we determined, they do not all correspond to the mean of the a posteriori distributions.

The covariance matrix of parameters was calculated to identify the significance and relevance of each parameter. The transport parameters of the southern pool-northern pool channel are negatively correlated with a correlation coefficient of -0.91 . This is consistent with the fact that both are involved in the same equation of the pool outflows. Total net water loss in the southern pool $\left(\mathrm{ETI}_{\mathrm{S}}\right)$ is poorly constrained by a normal curve and ranges between 2000 and $2400 \mathrm{~mm} \mathrm{yr}^{-1}$ with a mean value of $2200 \pm$ $117 \mathrm{mmyr}^{-1}$. Better constrained values of $2550 \pm 80$ and $2390 \pm 100 \mathrm{~mm} \mathrm{yr}^{-1}$ were obtained for the northern pool and the archipelagos, respectively. Outputs of the southern pool are dominated by flows towards the adjacent pools $\left(\mathrm{ETI}_{\mathrm{S}}<\right.$ $\left.Q_{\mathrm{SA}}+Q_{\mathrm{SN}}\right)$. The southern pool is thus a transit reservoir while the other two pools are dead-ends, dominated by the ETI. This is the reason why the latter two pools are more sensitive to the ETI parameter. ETI in the southern pool is negatively correlated to ETI in the northern pool with a correlation coefficient of -0.80 and to a lower extent to the ETI in the archipelagos $(r=-0.33)$. Such correlations reflect the hydrological setting of Lake Chad with a water supply of the southern pool towards the two other pools.

\subsubsection{Lake-level simulations}

Figure 6 illustrates the results of the Bayesian inverse approach for the hydrological modelling. All the accepted parameter sets were used to calculate the corresponding lakelevel time series. Mean, maximum, and minimum of the 3742 simulations are presented (Fig. 6) together with available observed lake-levels in the different pools.

Simulated and observed lake levels are generally in very good agreement, which is consistent with a Nash criterion above $0.94(S(\boldsymbol{m})<0.06)$ obtained for all simulations. The seasonal variability of the lake is well reproduced. Also well simulated is the disconnection that started in 1971 and the related drying of the northern pool and the archipelagos. Indeed the simulated and observed lake levels in the northern pool and in the archipelagos are below lake levels in the southern pool. Before 1972 and after 1988, inputs and simulated out- 

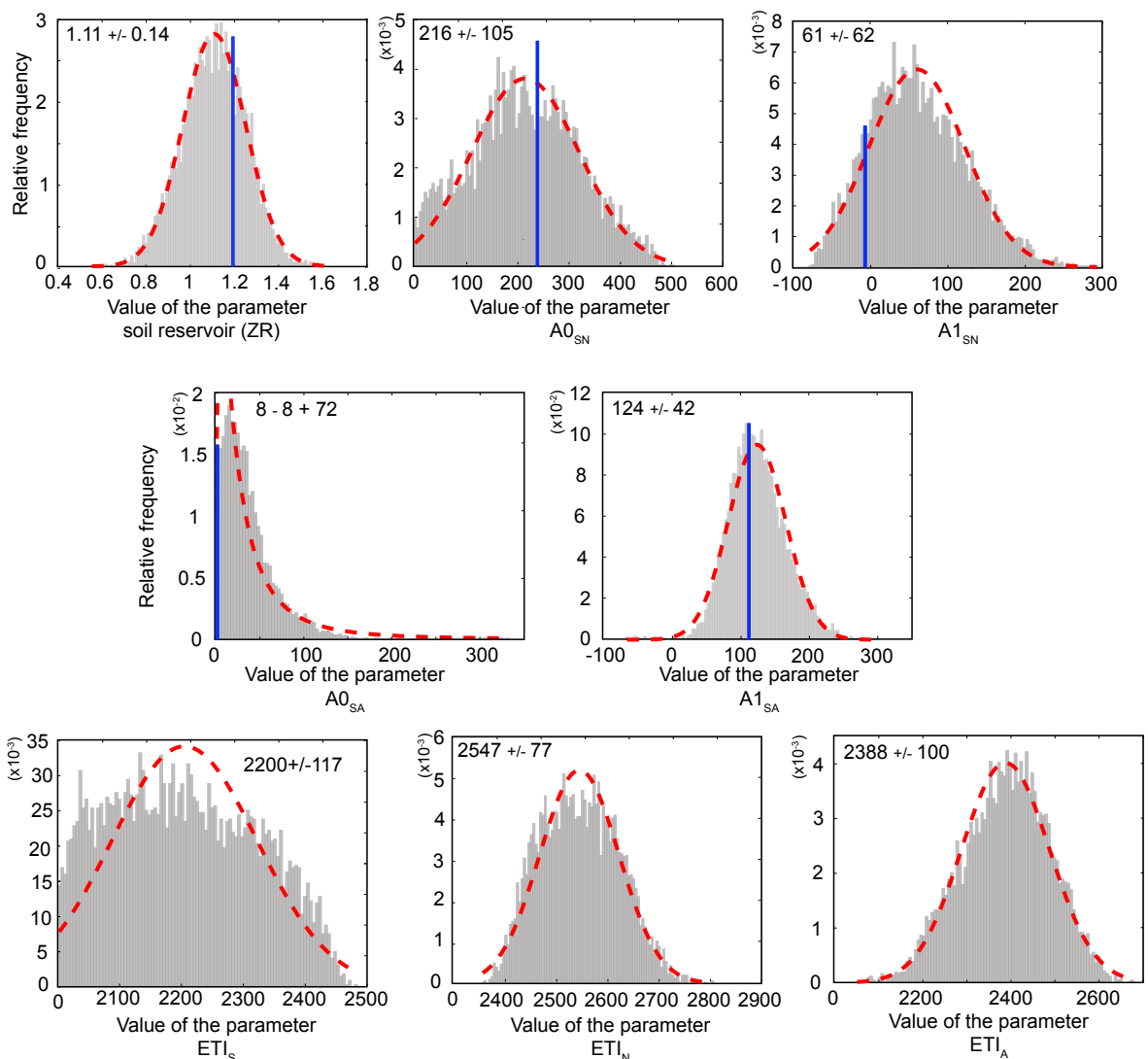

Figure 5. A posteriori distribution (PDF) for each parameter of the hydrological model. The histograms in grey were obtained after the Metropolis algorithm. The results are fitted by a normal or lognormal (A0 $\mathrm{SA}$ ) PDF curve in red. Mean and standard deviations of all parameters are displayed. The results obtained by Bader et al. (2011) are shown in blue.

Table 1. Calibrated values of $F_{\mathrm{I}}$ and $F_{\mathrm{E}}$ and the corresponding calculated values of $E$ (evaporation), $T$ (transpiration), and $I$ (infiltration) in $\mathrm{mm} \mathrm{yr}^{-1} . E, T$, and $I$ are also expressed as volumetric fluxes when the lake is at its normal state $\left(S=20000 \mathrm{~km}^{2}\right)$.

\begin{tabular}{lccccccr}
\hline & $\begin{array}{c}\mathrm{ETI} \\
\left(\mathrm{mm} \mathrm{yr}^{-1}\right)\end{array}$ & $F_{\mathrm{E}}$ & $\begin{array}{c}E \\
\left(\mathrm{~mm} \mathrm{yr}^{-1}\right)\end{array}$ & $F_{\mathrm{I}}$ & $\begin{array}{c}I \\
\left(\mathrm{~mm} \mathrm{yr}^{-1}\right)\end{array}$ & $E+T$ & $\begin{array}{r}T \\
\left(\mathrm{~mm} \mathrm{yr}^{-1}\right)\end{array}$ \\
\hline Southern pool & $2200 \pm 100$ & $0.8 \pm 0.2$ & $1700 \pm 400$ & $0.06 \pm 0.1$ & $130 \pm 200$ & $2070 \pm 200$ & 370 \\
Northern pool & $2550 \pm 100$ & $0.8 \pm 0.1$ & $2040 \pm 300$ & $0.11 \pm 0.01$ & $280 \pm 25$ & $2270 \pm 100$ & 230 \\
Archipelagos & $2390 \pm 100$ & $0.64 \pm 0.05$ & $1500 \pm 150$ & $0.36 \pm 0.06$ & $850 \pm 150$ & $1530 \pm 150$ & 30 \\
\hline
\end{tabular}

\begin{tabular}{lrrrr}
\hline & ETI $\left(\mathrm{m}^{3} \mathrm{yr}^{-1}\right)$ & $E\left(\mathrm{~m}^{3} \mathrm{yr}^{-1}\right)$ & $I\left(\mathrm{~m}^{3} \mathrm{yr}^{-1}\right)$ & $T\left(\mathrm{~m}^{3} \mathrm{yr}^{-1}\right)$ \\
\hline SP & $1.8 \times 10^{10}$ & $1.4 \times 10^{10}$ & $0.1 \times 10^{10}$ & $0.3 \times 10^{10}$ \\
NP & $2.4 \times 10^{10}$ & $1.9 \times 10^{10}$ & $0.3 \times 10^{10}$ & $0.2 \times 10^{10}$ \\
A & $0.6 \times 10^{10}$ & $0.4 \times 10^{10}$ & $0.2 \times 10^{10}$ & $0.007 \times 10^{10}$ \\
\hline
\end{tabular}

flows are found to be equal, leading to two stationary states of the lake, normal lake, and small lake while during the transition period between 1972 and 1988 water outputs exceed water inflows. Low levels in the archipelagos are not well simulated with any of the parameter sets, suggesting either that the chosen conceptualization cannot reproduce low levels, or measurement errors. The modelling uncertainty corresponds to the variance of all the simulations and is not constant between pools. The northern pool has a higher uncertainty with lake-level errors around $50 \mathrm{~cm}$ against $10 \mathrm{~cm}$ in the southern pool and the archipelagos. Because the $Z_{\mathrm{R}}$ parameter mainly influences the northern pool and because of its downstream position in the lake, all the modelling uncertainties are maximized in this region. 

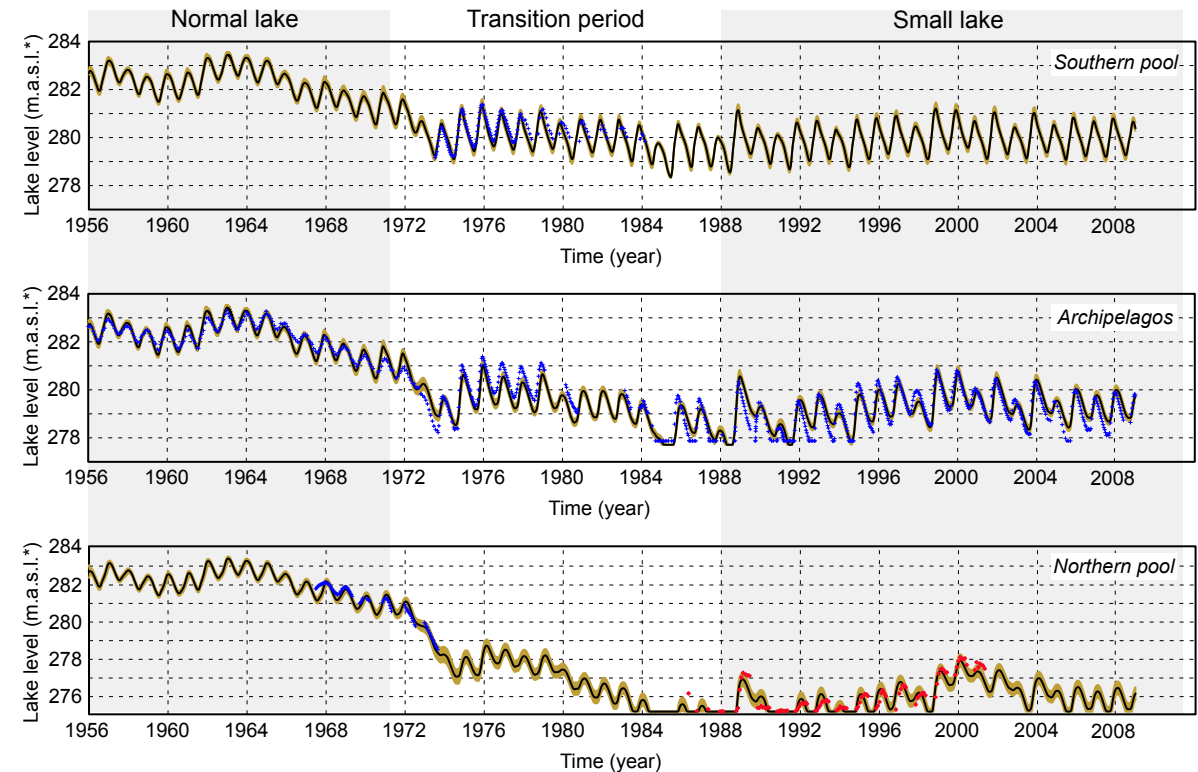

Figure 6. Lake levels observed and simulated over the 1956-2008 period. The black line represents the mean of all simulations and the brown area all the simulations for accepted parameter sets. The blue crosses are the lake-level observations and the red crosses are the surface observations converted into lake levels.

Table 2. Sensitivity tests on the geochemical simulations, based on the average isotopic composition and sodium concentration during the period 1968-1970. The first column is the input variable variation, the other columns the respective variations induced on the averaged simulated value during the 1968-1970 period in the southern pool (SP), the northern pool (NP), and the Archipelagos (A).

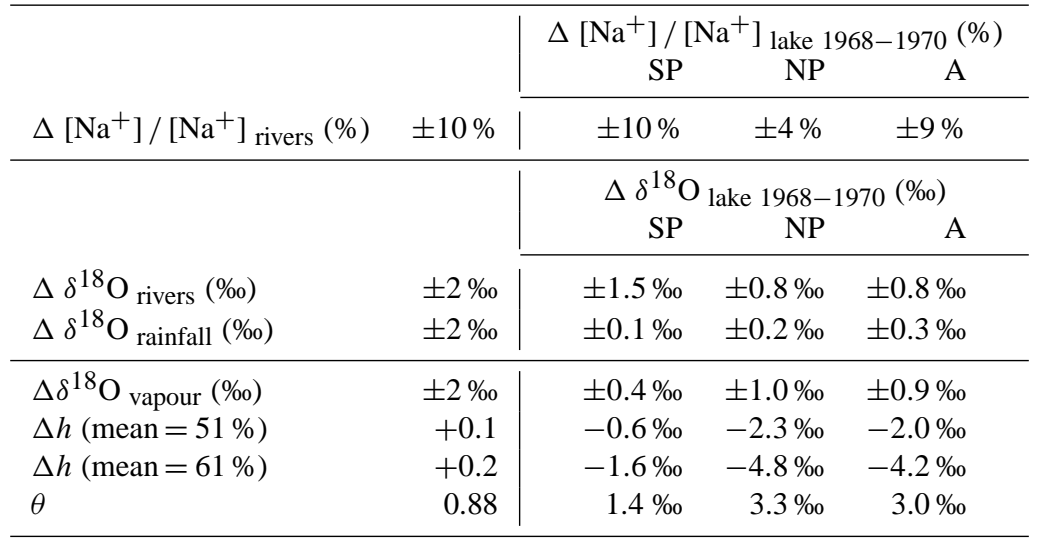

\subsection{Estimation of infiltration, evaporation, and transpiration}

\subsubsection{Sensitivity analysis of geochemical simulations}

A sensitivity analysis was conducted to assess the influence of the assumptions made on input data or kinetic fractionation factors on the simulated chemical and isotopic compositions of the lake. The sensitivity tests are carried on the isotopic composition and concentration averaged among the 1968-1970 time period, as it corresponds to the period with most accurate data (Table 2). The southern pool and the archipelagos simulated concentrations are very sensitive to variations of sodium in rivers. This effect is buffered in the northern pool. Similarly, the isotopic composition of the lake is sensitive to the isotopic composition of the rivers, essentially in the southern pool that is directly fed by the main tributary (Chari-Logone). As expected, the lake is not sensitive to rainfall as it constitutes a minor input to the lake. The northern pool and the archipelagos are sensitive to the isotopic composition of the vapour and to the relative humidity. This may be considered as a limitation of this model as these two variables and especially the vapour isotopic composition are poorly constrained.

However, the simulated slope of the evaporation line of $5\left(r^{2}=0.97\right)$, closely dependent on $h$ and $\delta_{\mathrm{A}}$ 


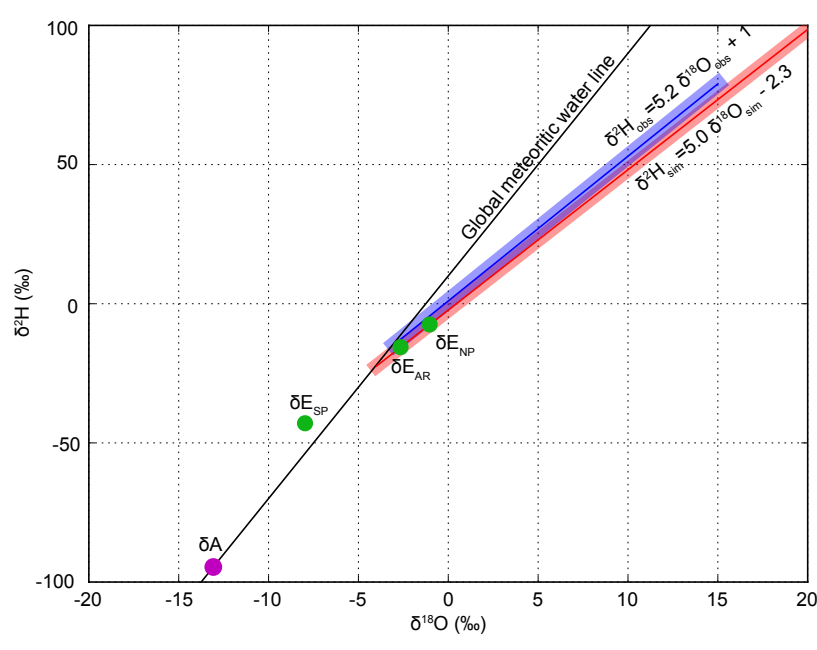

Figure 7. $\delta^{2} \mathrm{H}-\delta^{18} \mathrm{O}$ cross-plot showing the comparison between the observed evaporation line in Lake Chad in blue (according to Fontes et al., 1970b) and the simulated linear regression between $\delta^{2} \mathrm{H}$ and $\delta^{18} \mathrm{O}$ in Lake Chad in red. In addition, average isotopic compositions are showed for atmospheric moisture (purple) and simulated evaporates (green) above each pool (SP: southern pool, AR: archipelagos, and NP: northern pool).

(Vallet-Coulomb et al., 2006; Gonfiantini, 1986), is consistent with observations (Fig. 7). This supports the robustness of the isotopic modelling as well as the choice of the $\theta$ value. Indeed, as the $\theta$ parameter drives the proportion of kinetic fractionation on total evaporative fractionation, for both isotopic species, it also controls the slope of the evaporation line. The value of $\theta=0.5$ yields a slope of 5 for the simulated $\delta^{2} \mathrm{H}-\delta^{18} \mathrm{O}$ line, which matches the line obtained from measured water isotopic compositions in the whole Lake (Fontes et al., 1970b, and Fig. 7), while $\theta=0.88$ leads to a lower slope value (4).

\subsubsection{Estimates of evaporation $(E)$, infiltration $(I)$, and transpiration $(T)$}

The simulated values of $\left[\mathrm{Na}^{+}\right]$and of the isotopic composition of water in each pool were compared to the observations (Fig. 8). The simulations were performed for $F_{\mathrm{I}}$ and $F_{\mathrm{E}}$ varying between 0 and 1 , misfits are shown as functions of parameters $F_{\mathrm{I}}$ and $F_{\mathrm{E}}$ and parameter values yielding misfits below 1 are retained. The ranges of our best estimates for $F_{\mathrm{I}}$ and $F_{\mathrm{E}}$ are listed in Table 1. A globally acceptable agreement between simulations and observations is obtained except for high concentrations of sodium not simulated for the archipelagos and the northern pool. In the southern pool, the acceptance zones for the $F_{\mathrm{I}}$ and $F_{\mathrm{E}}$ misfit functions are larger, indicating again that this pool is less sensitive to $E$ and $I$ because its balance is dominated by the outflows towards the adjacent pools. $F_{\mathrm{I}}$ and $F_{\mathrm{E}}$ are better constrained in the northern pool and in the archipelagos.
$F_{\mathrm{I}}$ and $F_{\mathrm{E}}$ are consistent in each pool since $F_{\mathrm{I}}+F_{\mathrm{E}}$ is lower than $1 . F_{\mathrm{T}}$ can thus be calculated as $1-\left(F_{\mathrm{I}}+F_{\mathrm{E}}\right)$. Evaporation, infiltration, and transpiration derived from $F_{\mathrm{I}}, F_{\mathrm{E}}, F_{\mathrm{T}}$, and ETI in each pool are listed in Table 1. Evaporation is found to be higher in the northern pool than in the southern pool and the archipelagos. Infiltration is found to be significantly higher in the archipelagos while transpiration is significantly lower. The sum of evaporation and transpiration is higher in the northern pool than in the southern pool, which in turn is higher than in the archipelagos. Uncertainties on infiltration and evaporation are derived from the accepted ranges of $F_{\mathrm{I}}$ and $F_{\mathrm{E}}$. As expected, uncertainties associated with the calibrated values of evaporation and infiltration are higher in the southern pool. In the northern pool and in the archipelagos, uncertainties are lower but not negligible because of the scarcity and the precision of the data used to reconstruct the mean chemical and isotopic compositions of these pools.

\subsubsection{Geochemical simulations over the 1956-2011 period}

The results of the chemical and isotopic simulations are presented for the three pools on Fig. 9 over the 1956-2011 period using the values calculated above for $F_{\mathrm{I}}$ and $F_{\mathrm{E}}$.

The asymmetry of the lake is well represented in our modelling since the simulated concentrations are lower in the southern pool than in the northern pool and in the archipelagos. In the normal state, a simulated concentration ratio of 12 between the northern and the southern pools is obtained, while the ratio based on $\mathrm{Na}$ data is 11 . The observed isotopic enrichment, $\delta^{18} \mathrm{O}$ (northern pool) $-\delta^{18} \mathrm{O}$ (southern pool) is $5.7 \%$ against $5.3 \%$ or simulated isotopic enrichment (Fig. 9). While the most recent data cannot be truly compared to the simulations because of the bias of comparing local and averaged values, they provide some helpful information on a very different time period as compared to that of the calibration. In fact, simulations show a agreement with the recent data (after 1995, Fig. 9).

Despite uncertainty ranges on observed data, some discrepancies remain between the geochemical simulations and the observations, especially on the chemical simulations during the lake shrinking (between 1974 and 1978, Fig. 9). This could be linked, e.g., to the use of a constant value of $F_{\mathrm{I}}$, because the assumption of an infiltration flux only proportional to the lake surface area, although convenient, is an approximation of the Darcy's flux variations simultaneously dependent on lake-level, perimeter, and shorelines variations.

When using our model to produce a simulated chronicle of salt stock in the lake through time, we observe that the total stock of salt decreases when the lake volume drops (Fig. 9), which is in agreement with the observations by Carmouze (1976). 

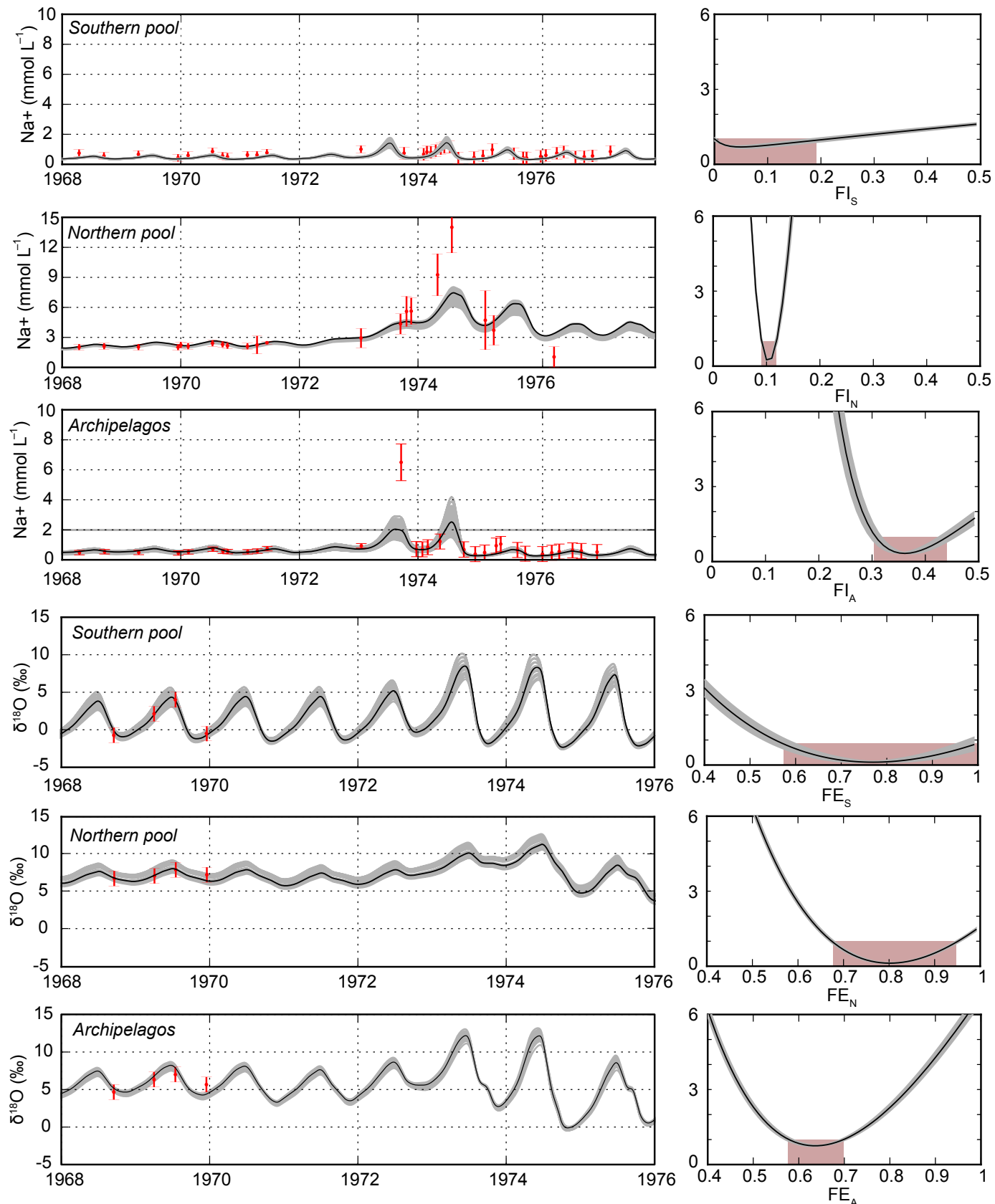

Figure 8. Calibration of $F_{\mathrm{I}}$ and $F_{\mathrm{E}}$ for each pool. Misfit functions are shown on the right, the grey area represents misfit functions calculated using all ETI ranges (Table 1), and black curves are misfit functions calculated using the mean calibrated value of ETI; brown rectangles show ranges of misfit functions below 1 . The fit between simulations and observations is shown on the left, grey curves show simulations with all accepted $F_{\mathrm{E}}$ and $F_{\mathrm{I}}$ values while black curves show the simulation with the optimum values of $F_{\mathrm{E}}$ and $F_{\mathrm{I}}$. 

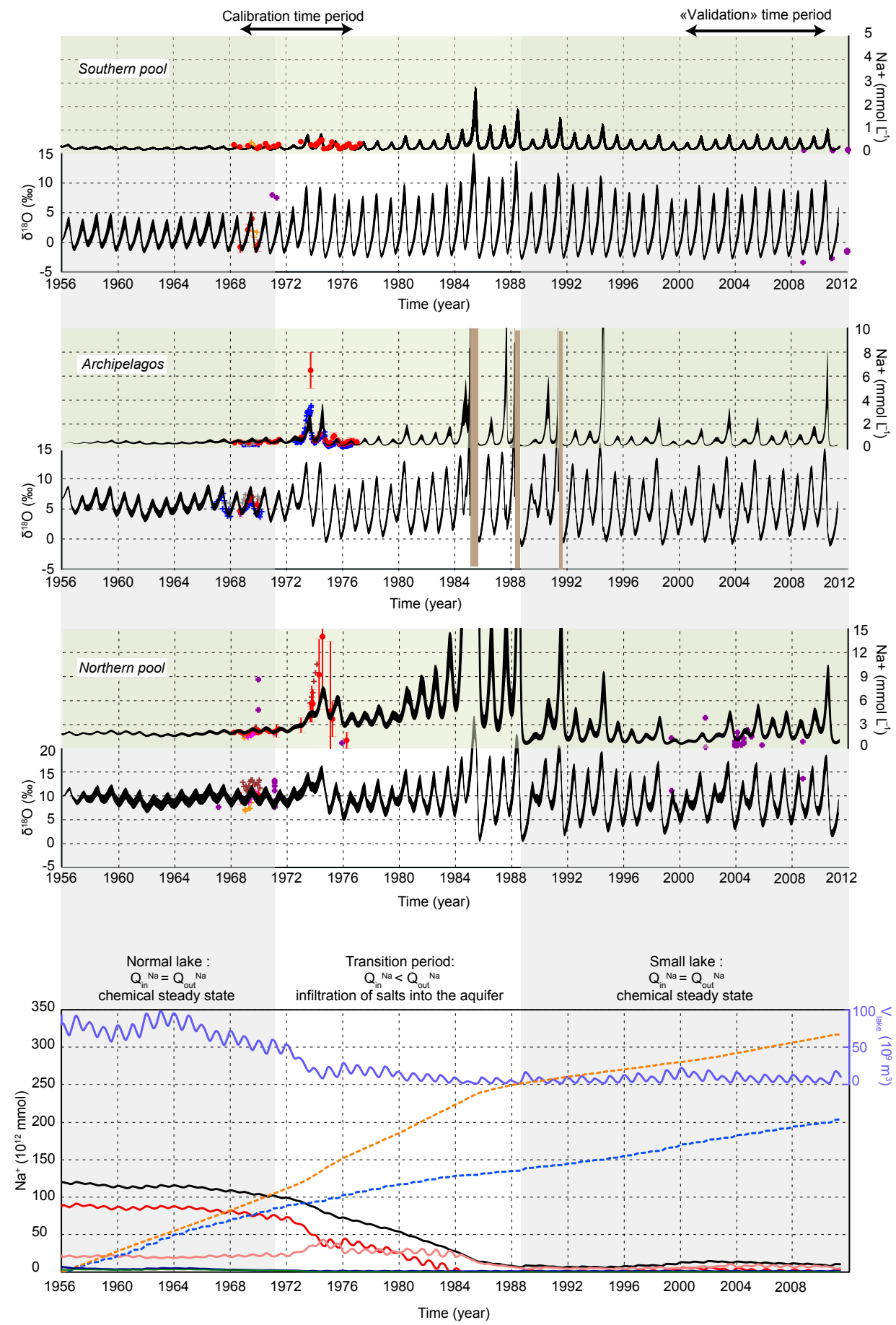

Figure 9. Results of the chemical and isotopic modelling for each pool. The simulated sodium concentrations and $\delta^{18} \mathrm{O}$ compositions from 1956 to 2011 are represented for the calibrated range of values for $F_{\mathrm{I}}$ and $F_{\mathrm{E}}$. The simulated sodium concentrations and $\delta^{18} \mathrm{O}$ compositions from 1956 to 2011 are represented for the calibrated range of values for $F_{\mathrm{I}}$ and $F_{\mathrm{E}}$. The measured sodium concentrations and $\delta^{18} \mathrm{O}$ compositions are represented by crosses for local measurements and by red dots for mean values. Colours refer to the corresponding monitored station (Fig. 2) except for purple which corresponds to local measurements away from the monitored stations. The different lake states are drawn by grey boxes and brown bands show episodes of total drying. The lower graph shows results of the simulated evolution of salt stocks: in the lake (black), in the northern pool (red), in the soil reservoir (pink), in the southern pool (green), and in the Archipelagos (blue). The cumulative stocks of sodium provided to the lake, essentially by rivers, and exported out of the lake by infiltration, are respectively represented by a blue dashed line and an orange dashed line. 


\section{Discussion}

\subsection{Evapotranspiration rates}

The calibrated value of ET in the southern pool of $2070 \mathrm{~mm} \mathrm{yr}^{-1}$ is slightly lower than local evaporation measurements $\left(2170 \mathrm{mmyr}^{-1}\right)$ but within the $10 \%$ uncertainty range. The calibrated value of ET in the northern pool of $2270 \mathrm{~mm} \mathrm{yr}^{-1}$ is $1.1 \times \mathrm{ET}$ in the southern pool. This $10 \%$ increase between south and north of Lake Chad is consistent with evaporation measurements and CRU data.

\subsection{Why is ET much lower in the archipelagos than in the southern pool?}

Low ET values are required in the archipelagos to reproduce the low isotopic enrichments and sodium concentrations. The value obtained $(1530 \pm 150)$ is significantly below the ET value found in the southern pool $(2070 \pm 200)$ while similar climatic conditions are observed. Several reasons for this apparent ET underestimation can be considered. A first cause could be the uncertainty on the surface-volume curve, in the case of an overestimation of the evaporative surfaces. Indeed, in the archipelagos, it is difficult to determine the free water surface because of its discontinuity and we assumed that it represents one-fourth of the southern pool surface as proposed by Bader et al. (2011). However, an error on lake surface would also affect ETI and not only ET. Secondly, the geochemical concentration of water entering the archipelagos from the southern pool could be incorrectly estimated. In the model, we assumed that it corresponds to the average concentration of the southern pool, but the water entering the archipelagos could be less concentrated and isotopically enriched than the mean value, since the connection between the two pools is not far from the mouth of the Chari-Logone river. Using the values of the Chari-Logone as inputs leads to a better estimate of the isotopic composition with a value in the normal state of $6 \%$ but sodium concentrations are still largely overestimated, the mean calculated concentration in the normal state being $1.3 \mathrm{mmol} \mathrm{L}^{-1}$ against the $0.5 \mathrm{mmol} \mathrm{L}^{-1}$ measured. This assumption is thus not sufficient to explain a potential underestimation of ET by the geochemical model. A third explanation could be related to the role of the vegetation and its potential influence on the chemical regulation during the transition period, as already suggested by Lemoalle (1979). We made the assumption of a constant $F_{\mathrm{T}}$ ratio and no salt exportation associated to transpiration. However, this relies on a constant vegetation cover with a steady-state turnover, corresponding to the natural vegetation cycle with no human exportation.

We made the assumption that evaporation and transpiration do not export salts. This assumption is robust for $E$ but for $T$ it relies on a steady state of the aquatic vegetation with a turnover corresponding to the vegetation cycle and no human exportation. Such a steady state is not valid since the lake surface has shrunk and the vegetation cover of the archipelagos has considerably increased, potentially storing $\mathrm{Na}$. Considering that the land-water contact surface is much more extensive in the archipelagos than in the other pools, transpiration on islands could also attract water under the islands, trapping salts similarly to the Okavango Delta (McCarthy and Ellery, 1994). Thus, if we assume that there is no climatic reason for a different ET in the archipelagos as compared to the southern pool, the missing evapotranspiration is $550 \mathrm{~mm} \mathrm{yr}^{-1}$ and the infiltration would be only $300 \mathrm{~mm} \mathrm{yr}^{-1}$. This missing flux can be attributed to transpiration as it has no influence on $\delta^{18} \mathrm{O}$ (not fractioning).

It is the first time that transpiration is accounted for in the Lake Chad budget. Our isotopic and chemical budgets estimate transpiration to be around $300 \mathrm{~mm} \mathrm{yr}^{-1}$ in the southern and northern pools and probably up to $550 \mathrm{~mm} \mathrm{yr}^{-1}$ in the archipelagos. This represents around $15 \%$ of the total water evaporation in the southern and northern pool and almost $40 \%$ in the archipelagos. This result is based on sparse isotopic measurements but is supported by the sensitivity analysis.

\subsection{Chemical regulation of the lake}

Our modelling of salt stocks shows that salt outputs exceed salt inputs during shrinking phases (Fig. 9), due to a combination of two factors: when the volume decreases (i) the waters are more concentrated and (ii) the ratio of infiltration over the lake volume is greater. Therefore, the drying episodes of the lake correspond to efficient periods of salt evacuation and they play a major role in the preservation of the freshness of Lake Chad both at seasonal and decadal timescales. The northern pool plays an important role in the chemical regulation of the lake since $95 \%$ of a conservative element such as $\mathrm{Na}$ is concentrated in the northern pool characterized by a higher volume and greater evaporation rates. Sodium precipitation simulated in the archipelagos during the 1980s accounts for less than $1 \%$ of the total evacuated sodium (Fig. 9). In our modelling, precipitates of natron definitively take $\mathrm{Na}$ out of the lake. If this is consistent with previous assertions of a rapid re-dissolution of salts by rainfall and infiltration into the Quaternary aquifer or of exportation by wind since the Harmattan is very strong in this region, these salts may also be dissolved during subsequent water level rising periods and thus return to the lake. In view of the low stock of precipitate salts in our simulations, this would induce weak uncertainties on the sodium balance.

\subsection{Infiltration rates and impact on the recharge of the regional aquifer}

In this study, the estimated total amount of water flowing out of the lake (infiltration) in its normal state is $6 \times$ $10^{9} \mathrm{~m}^{3} \mathrm{yr}^{-1}$, twice the $2.6 \times 10^{9} \mathrm{~m}^{3} \mathrm{yr}^{-1}$ value estimated by Bader et al. (2011). It is higher than previous estimates 
based on a steady-state chemical balance (Roche, 1980; Carmouze, 1983) yielding between 2 and $4 \times 10^{9} \mathrm{~m}^{3} \mathrm{yr}^{-1}$ but lower than measured values of infiltration by Isihoro et al. (1996) of $10 \times 10^{9} \mathrm{~m}^{3} \mathrm{yr}^{-1}$. Our estimate, under the assumption of mean composition waters flowing out of the whole lakebed, is a maximum since the waters mostly move to the aquifer at the lake shorelines with higher concentrations. Net recharge from the lake was estimated from hydrogeological modelling of the phreatic aquifer at 3 to $10 \times 10^{7} \mathrm{~m}^{3} \mathrm{yr}^{-1}$ by Leblanc (2002) and $28 \times 10^{7} \mathrm{~m}^{3} \mathrm{yr}^{-1}$ by Boronina and Ramillien (2008). The difference by almost 2 orders of magnitude between infiltration outflow from the lake and effective recharge of the phreatic aquifer can be explained by substantial evapotranspiration of infiltrated waters in the aquifer close to the shoreline. Coudrain-Ribstein et al. (1998) showed that in arid Sahelian environments, evaporation may reach down to $100 \mathrm{~m}$ depth into the ground and increases dramatically for a shallow water table (up to $200 \mathrm{~mm} \mathrm{yr}^{-1}$ at $0.5 \mathrm{~m}$ depth). This calculation is a minimum value of the groundwater uptake, since it does not take into account plant transpiration. To explain the difference between aquifer recharge and infiltration from the lake, $98 \%$ of the infiltration outflow from the lake must be evaporated, i.e. $5.9 \times$ $10^{9} \mathrm{~m}^{3} \mathrm{yr}^{-1}$.

All geochemical tracers indicate a restricted zone of lacustrine water influence in the phreatic aquifer. Stable isotopes are relevant tracers as the lake water is much more enriched (>5\%o) than rainfall (weighted-average of $-3 \%$ ). A regional cross section of the phreatic groundwater isotopic composition in the southern part of the lake points to an area no larger than $50 \mathrm{~km}$ from the lake of waters showing a lake-like isotopic signature (Vassolo, 2010). This result was also evidenced in the northern part of the lake (Fontes et al., 1970a). Chemical facies of the phreatic groundwaters also indicate lake-like waters up to $\sim 20 \mathrm{~km}$ from the shoreline (Djoret, 2000). We can thus reasonably consider that the evaporation of the infiltrated lake waters occurs in a band of between 20 and $50 \mathrm{~km}$ away from the lake. Therefore, the ratio of evaporative loss $\left(5.9 \times 10^{9} \mathrm{~m}^{3} \mathrm{yr}^{-1}\right)$ to potential evaporation surface leads to mean evaporation rates of between 362 and $134 \mathrm{~mm} \mathrm{yr}^{-1}$. This estimate is in the upper range of the values estimated by Coudrain-Ribstein et al. (1998) but is plausible because of (i) dense vegetation on the lake shorelines, and (ii) deep tree roots in the Sahelian band (Le Maitre et al., 1999).

In conclusion, although crucial for the chemical balance of the lake as it is the only outflow of salts, the amount of lake waters effectively recharging the aquifer is small because of the shallowness of the water table in the first few kilometres away from the lake shorelines, which leads to substantial evapotranspiration. However, it can be assumed that during the African humid period, when climatic conditions were less evaporative and the lake Mega-Chad covered a surface area of $340000 \mathrm{~km}^{2}$, the lake recharge to the Quaternary aquifer may have been larger.

\section{Conclusions}

This study represents a first effort at coupling hydrological, chemical, and isotopic budget models of Lake Chad. It allows a complete quantification of the total water losses, i.e. infiltration, evaporation, and transpiration in each pool and their associated uncertainties. Despite a sparse set of climatic, chemical, and isotopic data especially over recent time periods, we show that it is possible to constrain hydrological and chemical flows, leading to a better understanding of the hydrochemical response the lake to climate and environment forcings. Evapotranspiration is found to be 2070 and $2270 \mathrm{~mm} \mathrm{yr}^{-1}$ following a south-north gradient. Infiltration, assumed to be a constant and homogeneous rate over each pool bed, is estimated between 100 and $300 \mathrm{~mm} \mathrm{yr}^{-1}$, which represents around $10 \%$ of the total outflows. A low isotopic and chemical signature in the archipelagos supports the influence of transpiration by plants accounting for up to $40 \%$ of total outflows while transpiration represents about $15 \%$ in the other two pools.

We have confirmed that the surprisingly fresh waters of Lake Chad are explained by small infiltration flows but we also show that efficient evacuation of salts occurs during shrinking phases. The southern pool always remains fresh and the progressive evaporation in the other pools allows for the infiltration of more concentrated waters, which export salts towards the aquifer.

In the present-day context of huge climatic variability and demographic changes in this semi-arid area, there is a need to explore hydrological responses in vulnerable hydrosystems such as Lake Chad. Our coupled approach is one of the methods that can help understanding the hydrological behaviour of a lake at different timescales and in poorly instrumented areas. However, a coupled lake hydrogeological modelling would be necessary to fully tackle the groundwater-surface water dynamic issue.

\section{The Supplement related to this article is available online at doi:10.5194/hess-20-1599-2016-supplement.}

Acknowledgements. The authors are very grateful to JeanClaude Bader and Jean-Jacques Lemoalle (UMR G-EAU), who kindly provide us with their data set on Lake Chad system. Camille Bouchez also acknowledges Nicolas Cherpeau for his help on Metropolis algorithm. This work was supported by FFEM (Fond Français de l'Environnement Mondial) and by the Agence Nationale de la Recherche through the LABEX OT-MED (Objectif Terre: Bassin Méditerranéen http://www.otmed.fr/). This manuscript has benefited from the insightful comments of J. Gibson and S. P. Good.

Edited by: L. Wang 


\section{References}

Abderamane, H., Razack, M., and Vassolo, S.: Hydrogeochemical and isotopic characterization of the groundwater in the ChariBaguirmi depression, Republic of Chad, Environ. Earth Sci., 69, 2337-2350, 2013.

Aranyossy, J. and Ndiaye, B.: Etude et modélisation de la formation des dépressions piézométriques en Afrique sahélienne, J. Water Sci., 6, 81-96, 1993.

Archambault, J.: Les eaux souterraines de l'Afrique occidentale, Berger-Levrault, Nancy, France, 1960.

Bader, J., Lemoalle, J., and Leblanc, M.: Modèle hydrologique du Lac Tchad, Hydrolog. Sci. J., 56, 411-425, 2011.

Ballatore, T. J. and Muhandiki, V. S.: The case for a world lake vision, Hydrol. Process., 16, 2079-2089, 2002.

Beven, K.: A manifesto for the equifinality thesis, J. Hydrol., 320, 18-36, 2006.

Boronina, A. and Ramillien, G.: Application of AVHRR imagery and GRACE measurements for calculation of actual evapotranspiration over the Quaternary aquifer (Lake Chad basin) and validation of groundwater models, J. Hydrol., 348, 98-109, 2008.

Carmouze, J.-P.: Originalité de la régulation saline du lac Tchad, Comptes Rendus de l'Académie des Sciences. Série D: Sciences Naturelles, 275, 1871-1874, 1972.

Carmouze, J.-P.: La régulation hydrogéochimique du lac Tchad: Contribution à l'analyse biogéodynamique d'un système lacustre endoréique en milieu continental cristallin, $\mathrm{PhD}$ thesis, ORSTOM, Paris, 1976.

Carmouze, J.-P.: The hydrochemical regulation of the lake Chad, Réunion de travail sur la limnologie africaine, ORSTOM, Paris, 1-34, 1979.

Carmouze, J.-P.: Hydrochemical regulation of the lake, in: Lake Chad, Springer, the Netherlands, 95-123, 1983.

Chantraine, J.-M.: Analyses d'eaux du lac Tchad (année 1976 - 1er trimestre 1977), Tech. rep., ORSTOM, Njamena, 1977.

Chantraine, J.-M.: Evolution hydrochimique du lac Tchad de septembre 1973 à septembre 1975 au cours d'une phase de décrue, Cah. Orstom. Hydrobiol., XII, 3-17, 1978.

Chantraine, J.-M. and Lemoalle, J.: Analyses d'eaux du lac Tchad de septembre 1973 à décembre 1974, Tech. rep., ORSTOM, NDjamena, 1976a.

Chantraine, J.-M. and Lemoalle, J.: Analyses d'eaux du lac Tchad en 1975, Tech. rep., ORSTOM, NDjamena, 1976b.

Coe, M. T. and Foley, J. A.: Human and natural impacts on the water resources of the Lake Chad basin, J. Geophys. Res.-Atmos., 106, 3349-3356, 2001.

Cogley, J.: Runoff from the world's landmasses: Amounts and uncertainties at 2-degree resolution, Trent Clim. Note, 89, 3, 25, 1989.

Contoux, C., Jost, A., Ramstein, G., Sepulchre, P., Krinner, G., and Schuster, M.: Megalake Chad impact on climate and vegetation during the late Pliocene and the mid-Holocene, Clim. Past, 9, 1417-1430, doi:10.5194/cp-9-1417-2013, 2013.

Coudrain-Ribstein, A., Pratx, B., Talbi, A., and Jusserand, C.: L'évaporation des nappes phréatiques sous climat aride estelle indépendante de la nature du sol?, Comptes Rendus de l'Académie des Sciences-Series IIA-Earth and Planetary Science, 326, 159-165, 1998.

Craig, H. and Gordon, L. I.: Deuterium and oxygen-18 variations in the ocean and the marine atmosphere, in: Stable Isotopes in
Oceanographic Studies and Paleotemperatures, edited by: Tongion, E., Laboratorio de geologia nucleare, Pisa, 9-130, 1965.

Djoret, D.: Etude de la recharge de la nappe du Chari-Baguirmi (Tchad) par les méthodes chimiques et isotopiques, $\mathrm{PhD}$ thesis, Université d'Avignon et des Pays de Vaucluse, Avignon, 2000.

Dotto, C., Kleidorfer, M., Deletic, A., Rauch, W., McCarthy, D., and Fletcher, T.: Performance and sensitivity analysis of stormwater models using a Bayesian approach and long-term high resolution data, Environ. Modell. Softw., 26, 1225-1239, 2011.

Fontes, J.-C., Maglione, G., and Roche, M.-A.: Données isotopiques préliminaires sur les rapports du lac Tchad avec les nappes de la bordure nord-est, Cah. Orstom. Hydrobiol., 6, 1734, 1969.

Fontes, J. C., Gonfiantini, R., and Roche, M.-A.: Deuterium et oxygene-18 dans les eaux du lac Tchad, Isotopes Hydrol., IAEASM-129/23, 387-404, 1970a.

Fontes, J.-C., Maglione, G., and Roche, M.-A.: Elements d'hydrologie isotopique dans le bassin du lac Tchad, Peaceful Uses of Atomic Energy in Africa, IAEA, Vienna, 209-222, 1970b.

Gac, J.-Y.: Géochimie du bassin du lac Tchad: Bilan de l'altération de l'érosion et de la sédimentation, $\mathrm{PhD}$ thesis, ORSTOM, Paris, 1980.

Gac, J. Y., Droubi, A., Fritz, B., and Tardy, Y.: Geochemical behaviour of silica and magnesium during the evaporation of waters in Chad, Chem. Geol., 19, 215-228, 1977.

Gallaire, R.: Hydrologie en milieu subdésertique d'altitude: Le cas de l'AÏR (Niger), PhD thesis, Université de Paris 11, Orsay, 1995.

Gat, J. R.: Oxygen and hydrogen isotopes in the hydrologic cycle, Annu. Rev. Earth Pl. Sc., 24, 225-262, 1996.

Gat, J. R., Bowser, C. J., and Kendall, C.: The contribution of evaporation from the Great Lakes to the continental atmosphere: estimate based on stable isotope data, Geophys. Res. Lett., 21, 557560, 1994.

Gaultier, G.: Recharge et paléorecharge d'une nappe libre en milieu sahélien (Niger oriental): approches géochimique et hydrodynamique, $\mathrm{PhD}$ thesis, Université de Paris 11, Orsay, 2004.

Gee, G. W. and Hillel, D.: Groundwater recharge in arid regions: review and critique of estimation methods, Hydrol. Process., 2, 255-266, 1988.

Gibson, J.: Short-term evaporation and water budget comparisons in shallow Arctic lakes using non-steady isotope mass balance, J. Hydrol., 264, 242-261, 2002.

Gibson, J., Prepas, E., and McEachern, P.: Quantitative comparison of lake throughflow, residency, and catchment runoff using stable isotopes: modelling and results from a regional survey of Boreal lakes, J. Hydrol., 262, 128-144, 2002.

Giorgi, F.: Variability and trends of sub-continental scale surface climate in the twentieth century - Part I: observations, Clim. Dynam., 18, 675-691, 2002.

Gonfiantini, R.: Environmental isotopes in lake studies, in: Handbook of Environmental Isotope Geochemistry, Elsevier, New York, 2, 113-168, 1986.

Goni, I., Fellman, E., and Edmunds, W.: Rainfall geochemistry in the Sahel region of northern Nigeria, Atmos. Environ., 35, 43314339, 2001. 
Harris, I., Jones, P., Osborn, T., and Lister, D.: Updated highresolution grids of monthly climatic observations-the CRU TS3. 10 Dataset, Int. J. Climatol., 34, 623-642, 2014.

Horita, J., Rozanski, K., and Cohen, S.: Isotope effects in the evaporation of water: a status report of the Craig-Gordon model, Isot. Environ. Healt. S., 44, 23-49, 2008.

Hutchinson, C. F., Warshall, P., Arnould, E. J., and Kindler, J.: Development in arid lands: lessons from Lake Chad, Environment: Science and Policy for Sustainable Development, 34, 1643, 1992.

Isihoro, S. and Matisoff, G.: Groundwater recharge from Lake Chad, Limnol. Oceanogr., 35, 931-938, 1990.

Isihoro, S., Matisoff, G., and Wehn, K.: Seepage relationship between Lake Chad and the Chad Aquifers, Groundwater, 34, 819 $826,1996$.

Jasechko, S., Sharp, Z. D., Gibson, J. J., Birks, S. J., Yi, Y., and Fawcett, P. J.: Terrestrial water fluxes dominated by transpiration, Nature, 496, 347-350, 2013.

Jasechko, S., Gibson, J. J., and Edwards, T. W.: Stable isotope mass balance of the Laurentian Great Lakes, J. Great Lakes Res., 40, 336-346, 2014.

Jeremiah, E., Sisson, S. A., Sharma, A., and Marshall, L.: Efficient hydrological model parameter optimization with Sequential Monte Carlo sampling, Environ. Modell. Softw., 38, 283-295, 2012.

Krabbenhoft, D. P., Bowser, C. J., Anderson, M. P., and Valley, J. W.: Estimating groundwater exchange with lakes: 1. The stable isotope mass balance method, Water Resour. Res., 26, 2445-2453, 1990.

Kuczera, G. and Parent, E.: Monte Carlo assessment of parameter uncertainty in conceptual catchment models: the Metropolis algorithm, J. Hydrol., 211, 69-85, 1998.

LaBaugh, J. W., Winter, T. C., Rosenberry, D. O., Schuster, P. F., Reddy, M. M., and Aiken, G. R.: Hydrological and chemical estimates of the water balance of a closed-basin lake in north central Minnesota, Water Resour. Res., 33, 2799-2812, 1997.

Lauwaet, D., Van Lipzig, N., Van Weverberg, K., De Ridder, K., and Goyens, C.: The precipitation response to the desiccation of Lake Chad, Q. J. Roy. Meteor. Soc., 138, 707-719, 2012.

Le Coz, M., Delclaux, F., Genthon, P., and Favreau, G.: Assessment of Digital Elevation Model (DEM) aggregation methods for hydrological modeling: Lake Chad basin, Africa, Comput. Geosci., 35, 1661-1670, 2009.

Le Maitre, D. C., Scott, D. F., and Colvin, C.: Review of information on interactions between vegetation and groundwater, Water SA, 25, 137-152, 1999.

Lebel, T. and Ali, A.: Recent trends in the Central and Western Sahel rainfall regime (1990-2007), J. Hydrol., 375, 52-64, 2009.

Leblanc, M.: Gestion des ressources en eau des grands bassins semi-arides à l'aide de la télédétection et des SIG: application à l'étude du bassin du lac Tchad, Afrique, $\mathrm{PhD}$ thesis, Université de Poitiers, Poitiers, 2002.

Leblanc, M., Lemoalle, J., Bader, J.-C., Tweed, S., and Mofor, L.: Thermal remote sensing of water under flooded vegetation: new observations of inundation patterns for the "Small" Lake Chad, J. Hydrol., 404, 87-98, 2011.

Leduc, C., Sabljak, S., Taupin, J.-D., Marlin, C., and Favreau, G.: Estimation de la recharge de la nappe quaternaire dans le NordOuest du bassin du lac Tchad (Niger oriental) à partir de mesures isotopiques, Comptes Rendus de l'Académie des Sciences-Series IIA-Earth and Planetary Science, 330, 355-361, 2000.

Lemoalle, J.: Biomasse et production phytoplanctoniques du lac Tchad (1968-1976): Relations avec les conditions du milieu, PhD thesis, Doctorat d'Etat: Sciences naturelles: Universite Paris VI, Paris, 1979.

Lemoalle, J.: Lake Chad: a changing environment, in: Dying and Dead Seas Climatic Versus Anthropic Causes, Kluwer Academic Publishers, Dordrecht, 321-339, 2004.

Lemoalle, J., Bader, J.-C., Leblanc, M., and Sedick, A.: Recent changes in Lake Chad: observations, simulations and management options (1973-2011), Global Planet. Change, 80, 247-254, 2012.

Lemoalle, J., Magrin, G., Ngaressem, G., Ngounou Natcha, B., Raimond, C., and Issa, S.: Le développement du Lac Tchad: situation actuelle et futurs possibles, in: Expertise collégiale, IRD Editions, Marseille, 2014.

Lesht, B. M., Fontaine III, T. D., and Dolan, D. M.: Great Lakes total phosphorus model: post audit and regionalized sensitivity analysis, J. Great Lakes Res., 17, 3-17, 1991.

Maglione, G.: Geochime des evaporites et silicates neoformes en milieu continental confine Les depressions interdunaires du Tchad-Afrique, Travaux et Documents de l'ORSTOM, no. 50, ORSTOM, Paris, 1976.

Marshall, L., Nott, D., and Sharma, A.: A comparative study of Markov chain Monte Carlo methods for conceptual rainfall-runoff modeling, Water Resour. Res., 40, W02501, doi:10.1029/2003WR002378, 2004.

McCarthy, T. and Ellery, W.: The effect of vegetation on soil and ground water chemistry and hydrology of islands in the seasonal swamps of the Okavango Fan, Botswana, J. Hydrol., 154, 169193, 1994.

Merlivat, L.: Molecular diffusivities of $\mathrm{H}_{2}{ }^{16} \mathrm{O}, \mathrm{HD}^{16} \mathrm{O}$, and $\mathrm{H}_{2}$ ${ }^{18} \mathrm{O}$ in gases, J. Chem. Phys., 69, 2864-2871, 1978.

Monteith, J.: Weather and water in the Sudano-Sahelian zone, in: Soil Water Balance in the Sudano-Sahelian Zone, IAHS Publication vol. 199, 11-29, Institute of Hydrology, Wallingford, UK, 1991.

Mosegaard, K. and Tarantola, A.: Monte Carlo sampling of solutions to inverse problems, J. Geophys. Res.-Sol. Ea., 100, 1243112447, 1995.

NASA Earth Observatory: Africa's Disappearing Lake Chad, available at: http://earthobservatory.nasa.gov/IOTD/view.php? id=1240 (last access: 20 April 2016), 13 March 2001.

Olivry, J., Chouret, A., Vuillaume, G., Lemoalle, J., and Bricquet, J.: Hydrologie du lac Tchad, Editions de l'ORSTOM, Paris 1996.

Riou, C. and Dubois, G.: Premières mesures d'évapotranspiration potentielle en République du Tchad, Cahiers ORSTOM. Série Hydrologie, 4, 47-60, 1967.

Roche, M.-A.: Evolution dans l'espace et le temps de la conductivité électrique des eaux du lac Tchad d'après les résultats de 1908, 1957, 1962 à mars 1968, (Rapport provisoire), Cahiers ORSTOM, Série Hydrologie, 6, 35-78, 1969.

Roche, M.-A.: Geochemistry and natural ionic and isotopic tracing; two complementary ways to study the natural salinity regime of the hydrological system of Lake Chad, J. Hydrol., 26, 153-171, 1975.

Roche, M.: Tracage naturel salin et isotopique des eaux du systeme du Lac Tchad, These de Doctorat d'Etat, Travaux et Documents 
de l'ORSTOM, ORSTOM (Office de la Recherche Scientifique et Technique d'Outre-Mer) editions, Paris, 1980.

Rosenberry, D. O., Winter, T. C., Buso, D. C., and Likens, G. E.: Comparison of 15 evaporation methods applied to a small mountain lake in the northeastern USA, J. Hydrol., 340, 149-166, 2007.

Sacks, L. A., Lee, T. M., and Swancar, A.: The suitability of a simplified isotope-balance approach to quantify transient groundwater-lake interactions over a decade with climatic extremes, J. Hydrol., 519, 3042-3053, 2014.

Sarch, M.-T.: Fishing and farming at Lake Chad: institutions for access to natural resources, J. Environ. Manage., 62, 185-199, 2001.

Sarch, M.-T. and Birkett, C.: Fishing and farming at Lake Chad: responses to lake-level fluctuations, Geogr. J., 166, 156-172, 2000.

Schneider, J. and Wolff, J.: Carte géologique et cartes hydrogéologiques à 1/1.500.000 de la République du Tchad. Mémoire Explicatif, Tech. Rep. BRGM 209, BRGM, Orléans, 1992.

Tremoy, G., Vimeux, F., Mayaki, S., Souley, I., Cattani, O., Risi, C., Favreau, G., and Oi, M.: A 1-year long $\delta^{18} \mathrm{O}$ record of water vapor in Niamey (Niger) reveals insightful atmospheric processes at different timescales, Geophys. Res. Lett., 39, L08805, doi:10.1029/2012GL051298, 2012.

Troin, M., Vallet-Coulomb, C., Sylvestre, F., and Piovano, E.: Hydrological modelling of a closed lake (Laguna Mar Chiquita, Argentina) in the context of 20th century climatic changes, J. Hydrol., 393, 233-244, 2010.
Vallet-Coulomb, C., Legesse, D., Gasse, F., Travi, Y., and Chernet, T.: Lake evaporation estimates in tropical Africa (Lake Ziway, Ethiopia), J. Hydrol., 245, 1-18, 2001.

Vallet-Coulomb, C., Gasse, F., Robison, L., and Ferry, L.: Simulation of the water and isotopic balance of a closed tropical lake at a daily time step (Lake Ihotry, South-West of Madagascar), J. Geochem. Explor., 88, 153-156, 2006.

Vallet-Coulomb, C., Gasse, F., and Sonzogni, C.: Seasonal evolution of the isotopic composition of atmospheric water vapour above a tropical lake: deuterium excess and implication for water recycling, Geochim. Cosmochim. Ac., 72, 4661-4674, 2008.

Vassolo, S.: Lake Chad Sustainable Water Management, Project Activities, Tech. Rep. 3, LCBC and BGR, Hannover, 2010.

Vuillaume, G.: Bilan hydrologique mensuel et modélisation sommaire du régime hydrologique du lac Tchad, Cahiers ORSTOM. Série Hydrologie, 18, 23-72, 1981.

Welp, L. R., Lee, X., Kim, K., Griffis, T. J., Billmark, K. A., and Baker, J. M.: $\delta^{18} \mathrm{O}$ of water vapour, evapotranspiration and the sites of leaf water evaporation in a soybean canopy, Plant Cell Environ., 31, 1214-1228, 2008.

Zairi, R.: Étude géochimique et hydrodynamique du Bassin du Lac Tchad (la nappe phréatique dans les régions du Kadzell (Niger oriental) et du Bornou (Nord-Est du Nigéria)), PhD thesis, Université de Montpellier 2, Montpellier, 2008. 